Historic, Archive Document

Do not assume content reflects current scientific knowledge, policies, or practices. 



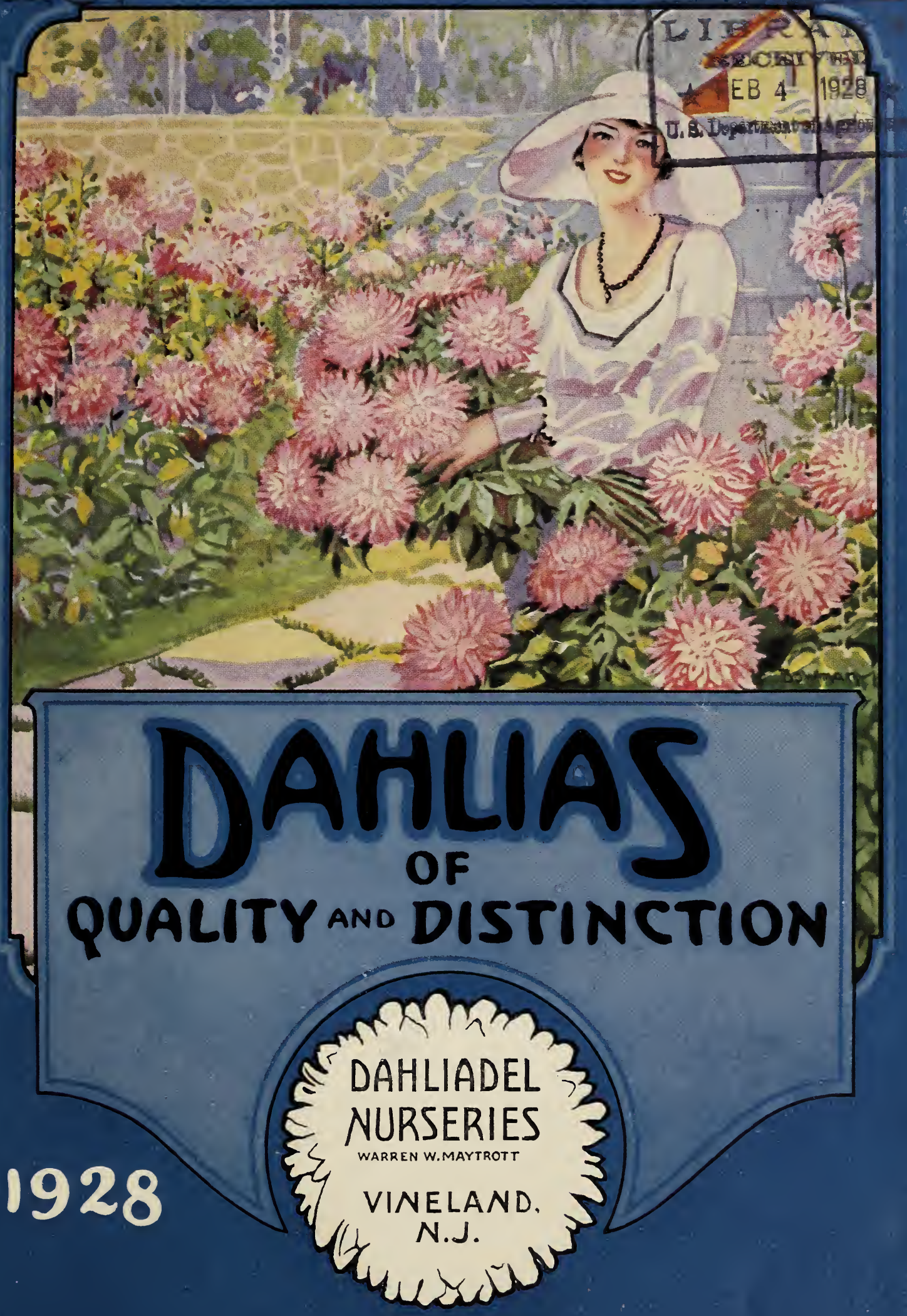




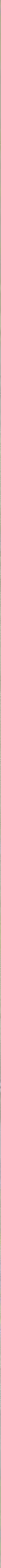




\section{POTASH-FED DAHLIAS}

It is certainly gratifying to hear of the wonderful results our customers and friends have had growing "Potash Fed Dahlias." They tell us of growing the finest dahlias they have ever had, and of all the prizes they have won. "Potash Fed Dahlias" is not a secret or just a trade name but a modern method of growing dahlias so that they are literally alive with energy, making failure well-nigh impossible. Our whole object in producing such stock is so that you may reap the harvest of blooms and our cultural directions scattered through the catalog are to aid you in growing them successfully.

The application of potash in combination with the other elements necessary for proper plant growth, (See Fertilizer) accompanied with the following conditions will produce Potash-Fed Dahlias.

First: Cultivation to aireate and sweeten the soil to keep the plant in a steady, healthy, growing condition. See Cultivating,

Second: Watering when necessary to make and keep the plant food available at all times. See Irrigation,

Third: MLost important of all is the health of the stock from which your plants or tubers were grown. This condition has its direct effect on the results obtained, for an unhealthy plant, whether stunted or diseased, cannot taker up potash or any other element of plant food in sufficient quantities while in this debilitated condition. Hence, unhealthy or diseased plants cannot be "Potash-Fed" even if grown in the midst of plenty.

If we were to say, "Corn-Fed Pork", at once we would see the pig eating corn, but when we say "Potash-Fed Dahlias," it is hard to visualize a dahlia feeding on potash as it is something we cannot see. It is necessary to have the right food available when it is needed and the animal or plant must be in a healthy state to make proper use of the food and give the results you are looking for.

In our 20 years with dahlias, we have dug and destroyed all unhealthy stock as soon as detected and the results are most gratifying. This is properly called roguing. To my knowledge, no one knows the exact cause of stunt or runt. However, we do know that roguing is the only practical way of eradication and believe the cause of stunt may be attributed to one or more of the following conditions:

First: From lowered vitality as a result of poor culture, lack of cultivation, etc.

Second: The ravages of attacking insects.

Third: The presence of a virus disease that causes a rotting of the feed roots.

\section{GREEN PLANTS}

There is still a varied opinion regarding plants, but we can again repeat our statements that Green Plants when properly grown from healthy stock give equal or better results than tubers. This they do for us. Some of the newer varieties listed in plants only are not because tuber stock is not available but because the plants listed are to be grown from selected stock where some stunt was present last season. By selecting the cuttings and again selecting the plants after rooting you are assured of the healthiest stock procurable.

\section{PLANTING DIRECTIONS}

After removing moss, and paper pot from plants that have been shipped, plant them with the top of the ball of dirt about 8 inches below the ground level and cover the top of the ball of dirt about 1 inch. Fill in gradually as the plant develops. In locan tions where there is danger of flooding, or poor drainage, do not plant as deep.

Cut all plants back to 2 or 3 pairs of leaves above the ground or at least pinch out the top to cause the plant to branch.

Water thoroughly and then cover with a basket or open crate for a few days as a partial protection from the sun and wind. For cut worms scatter Poison Bait the evening of planting. See "Cut Worms,"

Dahliadel Green Plants are properly grown and hardened for shipment and in our specially designed shipping box have been successfully sent all over the $\sigma$. S. 


\section{THE BEST FOR 1928}

\section{DAHLIADEL RECOMMENDATIONS}

CITY OF TRENTON (Prentice-Dahliade1)-This wonderful new decorative has all the qualifications of a first class exhibition dahlia. It is impossible to portray the sheen and luster or the brightness in the color reproduction found on the back cover of this catalog but it will give you a general idea. The bush grows strong and robust about 6 feet tall, producing flowers up to 12 inches across with perfectly full centers on long erect stems. A dahlia that will go beyond your expectation. D. S. of N. J. Cert. of Merit, 1927.

Tubers, $\$ 10.00 ;$ Plants, $\$ 5.00$

DAINTY MAID (Kemp)-See illustration, page 29.

ELSIE JANE (Schmidt-Dahliade1)-See page 14.

FORDHOOK GOLD CREST (Burpee)-Considered an outstanding decorative for the year. A spectacular autumn tint combining shades of yellow, salmon pink, and rose. Perfect flowers are held erect above all the foliage. Fine for cutting, garden or exhibition. D. S. of N. J. Cert. of Merit, 1927 Tubers, \$5.00; Plants, \$2.50

FORDHOOK PEARL (Burpee)-This artistic hybrid cactus is an early, free, and continuous bloomer, holding a full center through the season. Outer petals are straight while the center petals twist gracefully. A clear primrose yellow shading to a deep creamy white at the tips. Stems are long, bush $3 \mathrm{~T} / 2$ feet tall. D. S. of N. J. Cert. of Merit. $\quad$ Tubers, $\$ 5.00$; Plants, $\$ 2.50$

FORDHOOK SUNSHINE (Burpee)-Another large artistically formed decorative of autumn tints combining amber, bronze and gold. The blooms are equally good throughout the season. A. D. S. and D. S. of N. J. Certs. of Merit, 1927.

Tubers, \$5.00; Plants, \$2.50

FORT MONMOUTH (Kemp)-This giant hybrid cactus created much interest at the Eastern Shows this year. The predominating color being a rich claret with brightness unusual in darker tones. Flowers are full centered and well formed, borne on long stiff stems high above the foliage. A very prolific grower and bloomer, bush 7 to 8 feet high with flowers 13 inches in diameter. One of the outstanding novelties of the year. Winning in the largest bloom class at the Trenton Show.

Tubers, \$15.00; Plants, $\$ 7.50$

F. T. D. (F. \& M.)-Large exhibition decorative, a sport of Trentonian and an exact counterpart of its parent except in color, which is a rich Tyrian rose. This variety was named for the Florists' Telegraph Delivery. Flowers are held well above the foliage on rigid stems. Winner of the "Judge Shinn Silver Trophy" for the best 25 blooms at Atlantic City. D. S. of N. J. Cert. of Merit 1927. Tubers, \$7.50; Plants, $\$ 3.75$

GALLI-CURCI (Ha11)-This beautiful hybrid cactus dahlia was selected from the seedling class by Mme. Galli-Curci at the Dahlia Society of New Jersey Show on the Steel Pier, Atlantic City. A flower of extreme grace and charm similar in form to Waldheim Sunshine. A bright salmon orange with a brilliant luster and golden suffusion. It also won the Gold Medal as the best undisseminated seedling at the Camden Show. Stock limited.

Net, Plants, $\$ 7.50$

JANE COWL (Downs) - This wonderful hybrid decorative won the Garden and Home Builder Sweepstake Medal at New York and Cert. of Merit of the A. D. S. at Storrs, Conn. It is one of the most talked of novelties this season. Color a warm buff and old gold blending to bright salmon at the center. Bush growth is ideal with strong stems holding the giant flowers upright.

Tubers, $\$ 15.00 ;$ Plants, $\$ 7.50$

JEAN HARE (F. \& M.) - A very free blooming hybrid cactus similar in form to illustration of Sunkiss. Medium to tall bush growth. Stems upright and perfectly stiff. One of the most attractive autumn shade dahlias on account of its great size and beauty. Color, buff apricot with the outer petals of a golden bronze. Cert. of Merit D. S. of N. J. 1927.

Tubers, $\$ 10.00 ;$ Plants, $\$ 5.00$

JERSEY'S DAYBREAK (Waite)-This much admired decorative is Hermosa pink shading to creamy yellow in the center. Flowers of medium size with pointed centers, hold their splendid form throughout the season. The stems are rigid and the foliage is of a leathery texture. Stock limited.

Plants, $\$ \mathbf{5 . 0 0}$

JUDGE SHINN (Kemp)-One of the best hybrid decoratives, and an outstanding variety at the Eastern Show this season, winning Silver Medal at Atlantic City for the best unnamed seedling. A large artistic dahlia of great depth. Color a pleasing combination of gold and salmon, gold predominating at the center and salmon in the outer petals. The plant is a tall vigorous grower. This dahlia was named for the Hon. C. C. Shinn of Atlantic City who took an active part in our State Dahlia Show this year. 


\section{DAHLIADEL RECOMMENDATIONS-Continued}

KEMP'S VIOLET WONDER (Kemp)-The predominating color of this fine decorative dahlia is Napthaline violet, with an undertone of royal purple, lightening to faint bluish violet at the tips of petals. Deep flowers are as near perfect in form as possible, growing 10 inches and over in diameter. Stems are stiff, holding flowers a foot above the foliage. A truly outstanding variety keeping well when cut. Plant is a prolific bloomer, strong grower of spreading habit not susceptible to sucking insects. Awarded D. S. of N. J. Cert., A. D. S. Gold Medal Ribbon at New York in 1927.

Tubers, \$15.00; Plants, $\$ 7.50$.

LOIS DELANDER (Shinn-Dahliadel)-This fine decorative dahlia was selected by Miss America 1927 (Lois Delander) from the seedling class at the State Dahlia Show in Atlantic City on the Steel Pier. It is a beautiful pink with a white center on good erect stems. The petals are long and pointed and form a unique flower. To be offered in 1929.

MARTHA KEMP (Kemp)-This is a very refined and beautiful decorative dahlia. The color is a warm buff shading to apricot yellow at base of petals. The flowers are fully 8 inches in diameter, and 6 inches deep. One of the most lasting dahlias, the blooms usually remaining in good condition a week or longer after they are in full bloom. Does not shed its petals. A seedling of Shudows Lavender, but with more refined foliage. Plant about 6 feet and a strong healthy grower, prolific bloomer, and good tuber maker.

Tubers, \$10.00; Plants, $\$ 5.00$

MY MARYLAND (Downs) - This graceful broad petaled hybrid cactus is a rich bright pink, each petal tipped with ivory. Flowers are large on strong stems. Received the Garden \& Home Builder Achievement Medal at Atlantic City, the A. D. S. Cert. of Merit at Storrs and won in New York as the best undisseminated hybrid cactus.

Tubers, \$15.00; Plants, $\$ 7.50$

SANHICAN'S NYMPH (F. \& M.)-This large decorative is very attractive especially for exhibition. It is a deep flower with a very full center. Color, a beautiful primrose yellow with a shade of fawn rose on the reverse of petals, the latter color showing up more clearly at the center of the flower. Flowers facing upward on strong stems.

Tubers, \$7.50; Plants, $\$ 3.75$

SANHICAN'S PEACH (F. \& M.)-A fluffy decorative of good size and great charm. In color it is exactly the shade of a ripe California peach with a real peach-cheek glow. It's attractiveness is further enhanced by the oddly twisted petals. Rich dark green foliage, upright stems and good habit of growth. Tubers, $\$ 6.00$; Plants, $\$ 3.00$

THE LEMONADE (Ward)-Although yellow dahlias are plentiful this grand decorative is beconing very popular because of its beauty, size, erect stems, good habit of growth and wonderful keeping qualities. Color clear canary yellow.

Tubers, \$5.00; Plants, \$2.50

WALDHEIM SUNSHINE (Peacock)-This giant yet graceful hybrid decorative dahlia is one of the very best for this season. A true deep yellow that will show up yellow under artificial light. The reflex is darker and there is a rich golden suffusion around the beautiful full high center. The bush growth is ideal, the strong erect stems hold the flowers facing upright. It is a sturdy grower and free bloomer. The centers were perfectly full when killed by frost in November. Illustrated on inside front cover. Stock limited.

Tubers, \$25.00; Plants, $\$ 12.50$

\section{INTRODUCTIONS}

\section{That Have Stood the Test. Found Classified in the Catalog.}

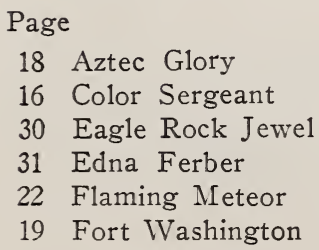

Page

$\begin{array}{ll}16 & \text { Color Sergeant } \\ 30 & \text { Eagle Rock Jewel } \\ 31 & \text { Edna Ferber } \\ 22 & \text { Flaming Meteor } \\ 19 & \text { Fort Washington }\end{array}$

$\begin{aligned} & \text { Page } \\ & 5 \text { Harry Mayer } \\ & 13 \text { Jack O’Lantern } \\ & 17 \text { Lady Lyndora } \\ & 21 \text { La Roda } \\ & 5 \text { Monmouth Jewel } \\ & 28 \text { Naagles Roem }\end{aligned}$

Page

13 Queen of the Garden Beautiful

23 Santa Anna

25 Silverado

11 Watchung Sunrise 


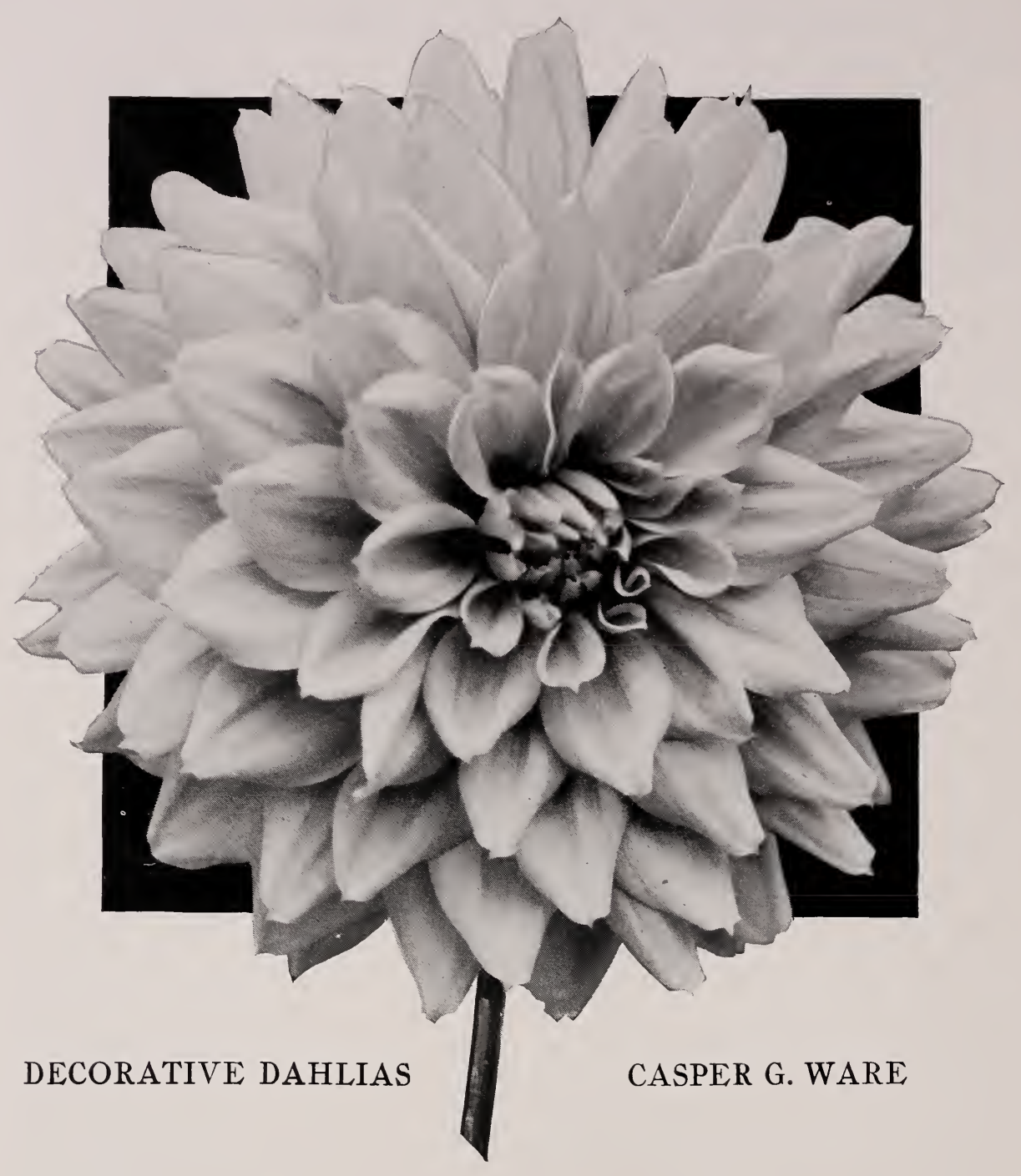

AMUN RA (Seal)-Described as resembling a setting sun. Flowers 10 inches. Outer petals are a gorgeous shade of copper and orange shading to gold and amber and deepening in the center to a reddish bronze.

AUTUMN QUEEN (Fisher and Masson)-We have in this variety real commercial qualities, substance, size, stem, and floriferousness. The petals curl just enough to make the flower artistic. Color deep peach to amber. Tubers, \$2.00; Plants, \$1.00.

AZALEA (Boston)-Large decorative with rather flat and pointed petals. Color, soft yellow, outer petals shaded pink.

BREEZE LAWN (Dreer)-Fiery vermilion; perfect form. Flowers often over eight inches across. Compact grower, early and free bloomer.

CASPER G. WARE (Bowen-Dahliade1)-This is truly a dahlia of many uses. When grown natural without disbudding you have an ideal flower for bedding or hedge effect as the bush grows 3 to 4 feet with a mass of blooms throughout the season. For exhibition or cut flowers prune out leaving only 4 to 8 shoots and by disbudding you will have blooms up to 10 inches in diameter with full centers until frost. It is one of the best and outstanding varieties especially for keeping qualities. Color a pleasing shade of bright silvery violet rose. D. S. of N. J. Certificate of Merit. 


\section{DECORATIVE DAHLIAS-Continued}

CHAMPAGNE (Boston)-Not only is this dahlia wonderful for its size and rigid stem, but its distinct coloring, unique form and freedom of flowering make it very popular. Color, golden champagne with chamois shadings.

$\$ 1.50$

ELLINOR VANDERVEER (Seal)-A highly recommended decorative of great size and wonderful beauty. Glowing satiny, rose-pink with darker shadings, of great depth and substance. Excellent stems and bush growth.

Tubers, \$2.50; Plants, $\$ 1.25$

FAITH GARIBALDI (Boston)-Large flowers of great depth, deep rose color shading lighter on outer petals. An excellent decorative for exhibition. A strong free grower with good stems.

Tubers, $\$ 2.50$; Plants, $\$ 1.25$

HARRY MAYER (Reed)-You could not wish for a finer exhibition dahlia. It has size, depth, wonderful stem, holds an even full center, and bush grows sturdy and healthy. Color, beautiful silvery pink with a rose pink reverse. A very attractive and satisfactory dahlia.

Tubers, $\$ 10.00 ;$ Plants, $\$ 5.00$

KITTIE DUNLAP (Boston)-A dahlia very similar to Mrs. I. De Ver Warner in color and size, but differing in form. A good keeper on fine stems. Color, an American Beauty shade.

$\$ 1.00$

LOTUS (Boston)-Rather distinct in formation. Flowers large with petals broad and flat cupping toward the center, like a water lily. Color, bright lively orange.

LYDIA POOLE-Large lavender pink, with excellent stems. A very strong grower, desirable for exhibition.

Tubers, $\$ 2.00$

MARCELLA (Gill)-A delightful clear, soft pink of perfect form, held erect on individual stems. Exceptionally free bloomer of medium size. Fine for cutting.

.25

MARGARET MASSON (F. \& M.)-Wonderful exhibition variety of a beautiful silvery pink of great depth and size, excellent keeping variety, and flowers are produced abundantly on stiff stems. Certificate 1924 .

Tubers, \$2.50; Plants, $\$ 1.25$

MISS CALIFORNIA (Pelicano) Decorative-IVon the Santa Barbara Trophy in 1926. Blooms are 6 to 9 inches across held well above the foliage on strong erect stems. Color described as an oriental fuchsia. A fine early bloomer good for commercial or exhibition uses. Bush similar to Mrs. Carl Salbach. Tubers, \$3.50; Plants, \$1.75

MONMOUTH JEWEL (Kemp) Decorative-A seedling of Amun Ra. Color bitter sweet orange, shading lemon chrome at base of petals. Large, well formed flowers held well above the foliage on strong stiff stems. Plants are strong and healthy growers resistant to leaf-hoppers.

Tubers, \$7.50; Plants, $\$ 3.75$

MR. CROWLEY (Broomall)-A beautiful exhibition dahlia. Although a compact grower, good stems can be produced by disbudding. Fine for garden effect when grown natural. Color, glowing salmon pink, base of petals yellow.

.75

MRS. I. DE VER WARNER (Marean)-No first class collection of dahlias should be without this wonderful variety which is a universal favorite. Color, a clear, bright lilac rose. The plant is a strong, ujen grower and the giant flowers can be produced on stems up to five feet in length by pruning and disbudding.

ROSA NELL (Broomall)-Color bright Tyrian rose with notched petals. This dahlia grows to good size on long erect stems. Bush tall and upright.

SALBACH'S WHITE (Salbach)-We have here the best all around white as flowers are uniform, of good substance and keeping qualities, borne profusely on long stiff stems, making it ideal for commercial and exhibition uses. The blooms are ivory white 6 to 8 inches in diameter, held erect on healthy bushes which are about 5 feet tall.

Tubers, \$7.50; Plants, \$3.75

SNOWDRIFT (Broomall)-Giant, pure-white deep flower with broad waxy petals. Has a good sten by pruning and disbudding. Fine for exhibition and garden.

UNCLE TOM (Reed-Adams) Decorative-The deepest garnet dahlia that we have ever seen, nearly black. Rich and artistic with petals like the very finest velvet. Flowers are very large, held erect on long stiff stenns. A good keeper and a color needed to finish the dahlia garden.

Tubers, $\$ 5.00 ;$ Plants, $\$ 2.50$ 


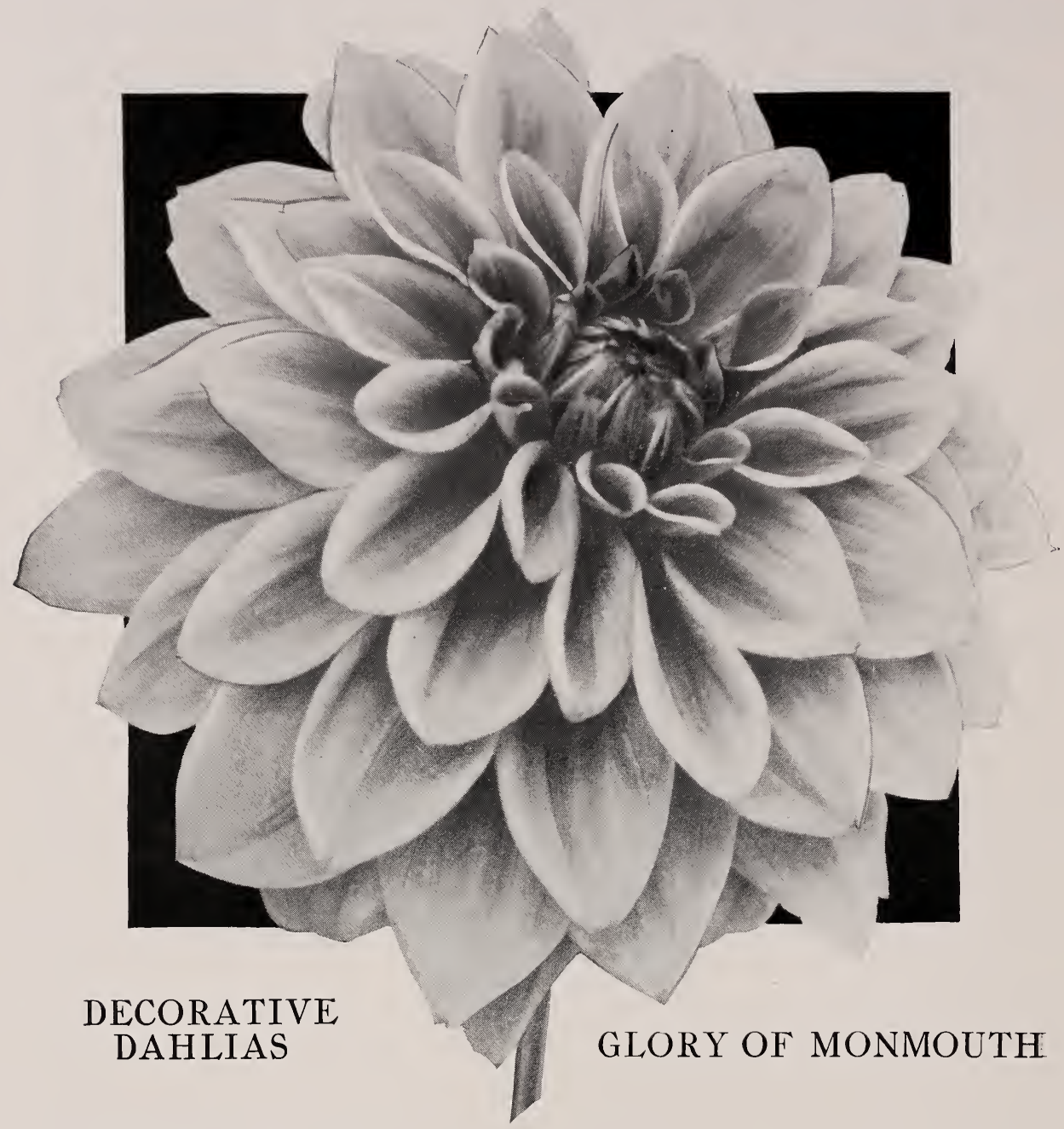

DAKOTA (Marean)-A good exhibition variety. Color a deep tone of rich coral-red with coppery suffusion. This strong growing variety is very satisfactory.

.75

ELITE GLORY (Kennedy)-The sensational rich red decorative which is considered a "break" in dahlia novelties. Unquestionably large and of good substance.

Tubers, $\$ 5.00$; Plants, $\$ 2.50$

EMBASSADOR (Boston)-Large blooms on stiff stems. Color, deepest shade of red or maroon. Tall grower and a good bloomer.

GLORY OF MONMOUTH (Kemp)-A really beautiful novelty. Color, salmon pink with light orange at the base of petals. The bush is of rather compact branching habit, literally covered with blooms, making it a beautiful specimen. Flowers are of a heavy texture 6 to 8 inches across and 4 inches deep, produced on long sturdy stems. Good keeping qualities and artistic coloring make it a wonderful garden and exhibition dahlia.

Tubers, $\$ 5.00$; Plants, $\$ 2.50$

JANE HALL (Peacock) -A full high centered decorative with petals reflexing to stem. Blooms well above the foliage on stout stems. Color, buff yellow with bronzy suffusion. 


\section{DECORATIVE DAHLIAS-Continued}

KEMP'S LAVENDER (Kemp)-Another free blooming variety of regular form and good substance. The violet mauve flowers are large with full centers.

Tubers, \$7.50; Plants, \$3.75

M. F. HEAPHY (Murphy) Decorative-Large deep flowers of deep velvety crimson carmine with reddish purple shadings. An early bloomer with good stems. Bushes 4 feet.

Tubers, \$3.50; Plants, $\$ 1.75$

MORDELLA (Kemp)-Apricot buff, beautiful under artificial light. Flowers large and gracefully formed on good stems. A tall grower.

Tubers, \$2.50; Plants, \$1.25

MR. ALEX. WALDIE (Broomall)-Color, cream overlaid salmon pink. Similar to Bonnie Brae but better form, stem, and bush growth. A real exhibition variety.

MR. C. H. DRESSELHUYS (Sluis and Groot)-Popular with the commercial grower because of its productiveness and keeping qualities. Medium sized blooms on long stems. Easily replaces Delice for color and is as free a bloomer as Delice is shy. Soft rose pink, shading lighter.

PATRICK O'MARA (Vincent)-Soft orange buff slightly tinged with rose. Good for cutting. Flowers 5 to 6 inches across. The broad flat petals twist and curl making an artistic flower.

SUNNY JERSEY (Dahliadel, 1925)-This dahlia, although somewhat similar in color to Eastern Star, is distinctly different in form and habit. It is an exceptionally free bloomer with flowers a foot or more above the foliage on erect stems. Color, lemon yellow, with golden suffusion. Scored 85 Exhibition and 90 Commercial at the D. S. of N. J. Trial Grounds.

Tubers, $\$ 1.50$; Plants, $\$ 1.00$

TRENTONIAN (F. \& M.)-The color is a wonderful blending of old gold, amber and coppery bronze, with a center zone of reddish bronze. Its broad, leathery petals are well placed making a flower of good lasting qualities. This flower is highly recommended either for garden or exhibition. Cert. D. S. of N. J.

Tubers, $\$ 2.00 ;$ Plants, $\$ 1.00$

The following directions are based upon years of practical experience and may be of value in solving some of your cultural problems. These suggestions should be changed to suit the local requirements. However, we sincerely believe that the fundamental principals involved will apply throughout the country.

\section{FERTILIZERS}

Of the ten elements considered absolutely necessary to plant growth, we find nitro. gen, phosphorus and potassium the prime essentials and the ones most lacking.

Nitrogen stimulates the growth above ground, producing large bushes and flowers, but if used to excess the flowers will be soft, wilting readily, and the bushes will be over. grown, and lower the vitality of the tubers.

Phosphoric acid increases the root development, especially the lateral and fiberous roots, strengthens the plant growth and gives substance to the bush and flowers. It also aids in ripening the tubers. This element is found in bone meal, with a small amount available in manures.

Potash is the balancing agent for nitrogen and phosphoric acid. It gives color to the flowers and foliage, and vigor and tone to the plant in general. It is an essential in starch formation and aids in the maturing of well-nourished tubers.

FERTILIZER to be applied before planting. Scatter broadcast after spading and mix thoroughly into the top soil to every 100 square feet of ground or to each 10 dahlia hills.

5 ib. Raw Bone Meal

10 lbs. Unleached Wood Ashes or

1 Ib. Muriate or Sulphate of Potash, not both.

Bone meal may be doubled if soil is very poor.
FERTILIZER or TOP DRESSING to be applied about August 15.

Scatter broadcast over ground not closer than 6 inches nor more than 18 inches from the stalk and rake in, to every 10 hills.

11/2 $2 b$. Raw Bone Flour

11/2 26 . Animal Tankage or

4 lb. Sheep Manure, not buth

5 ib. Unleached Wood Ashes or

$1 / 2$ lb. Muriate or Sulphate of

Potash, not both. 


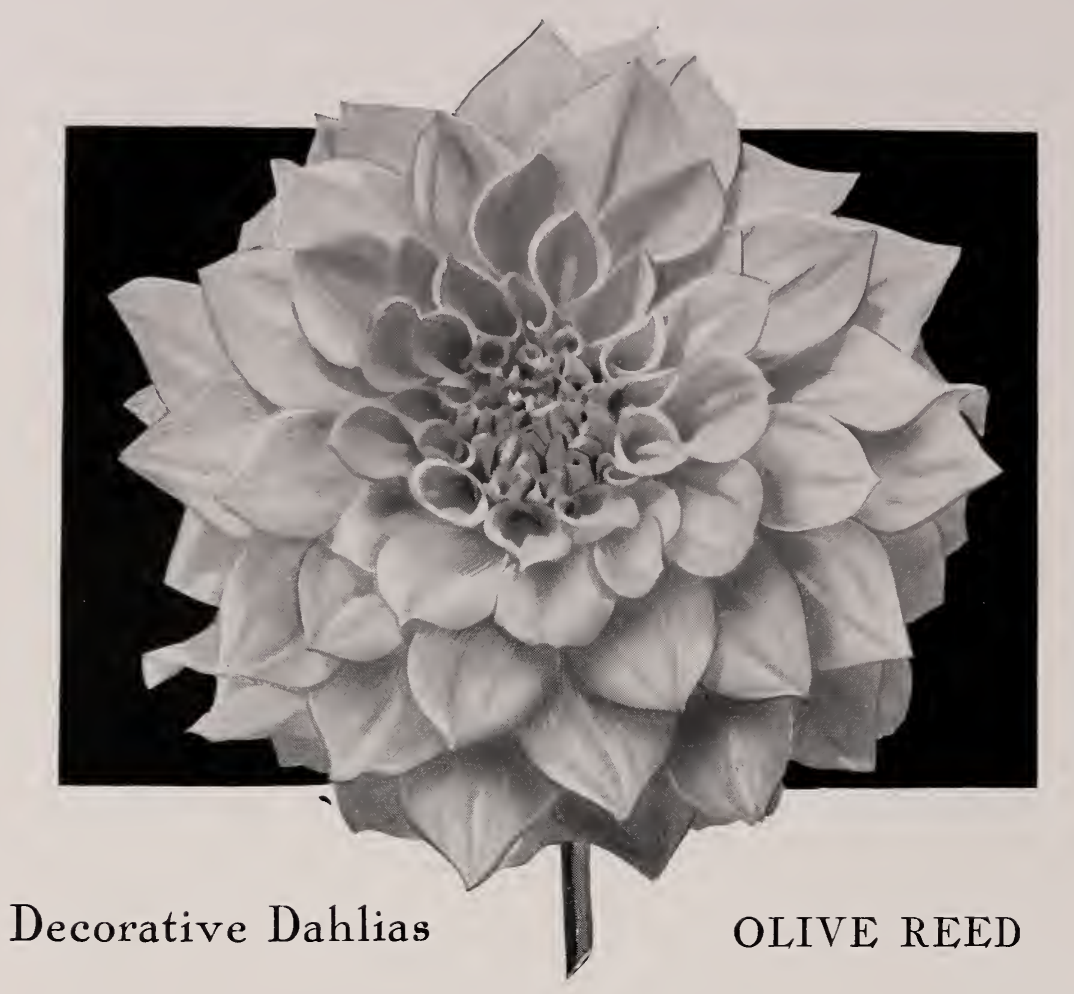

BETTY (Dahliadel)-Large flowers of good substance, excellent stem and bush growth. Color, canary yellow, faintly suffused salmon. As the flowers develop the outer petals open back forming a flower of great depth with a full high center.

$\$ 1.00$

CARMENCITA (Boston)--Bush rather dwarf, but flowers have good stems. Color, yellow, very lightly striped red. The artistic formation of the flower makes it popular.

$\$ 1.00$

DR. TEVIS (Tevis)-A very attractive and popular dahlia. Color, bronzy old gold, shaded and suffused violet rose. A tall grower with good stems.

.50

EARLE WILLIAMS (Doolittle)-One of the best bi-colored dahlias. A pleasing scarlet distinctly tipped white with an occasional bloom solid red. Flowers deep and large with full centers of regular form on erect stems.

$\$ 1.00$

HALVELLA (McWhirter)-A massive dahlia on long stem, with good cutting and exhibiting qualities. Flowers are a beautiful shade of rose pink a little darker than Jersey's Beauty. Profuse early bloomer.

$\$ 1.00$

NOBILIS (Doolittle)-Very similar to Earle Williams in form and color, except that the white predominates. Color, crimson and white. A real exhibition and commercial variety.

$\$ 1.00$

OLIVE REED (Seal) Decorative-There are quite a few good yellows of recent introduction but this is a good bright yellow with deep petals. Large full flowers on good stems. One of the best.

Tubers, \$5.00; Plants, $\$ 2.50$

PRIDE OF CALIFORNIA (Lohrman)-A large crimson red, with full dark center on good stems. Fine for garden and exhibition; petals notched.

WHEN TO PLANT. One of the common errors in the culture of dahlias is planting too early. In the latitude of Philadelphia they should be planted between May 15 and June 15. Farther north, where the hot spells in July and August are less harmful and early frosts are prevalent, plant as soon as danger of frost is over. 


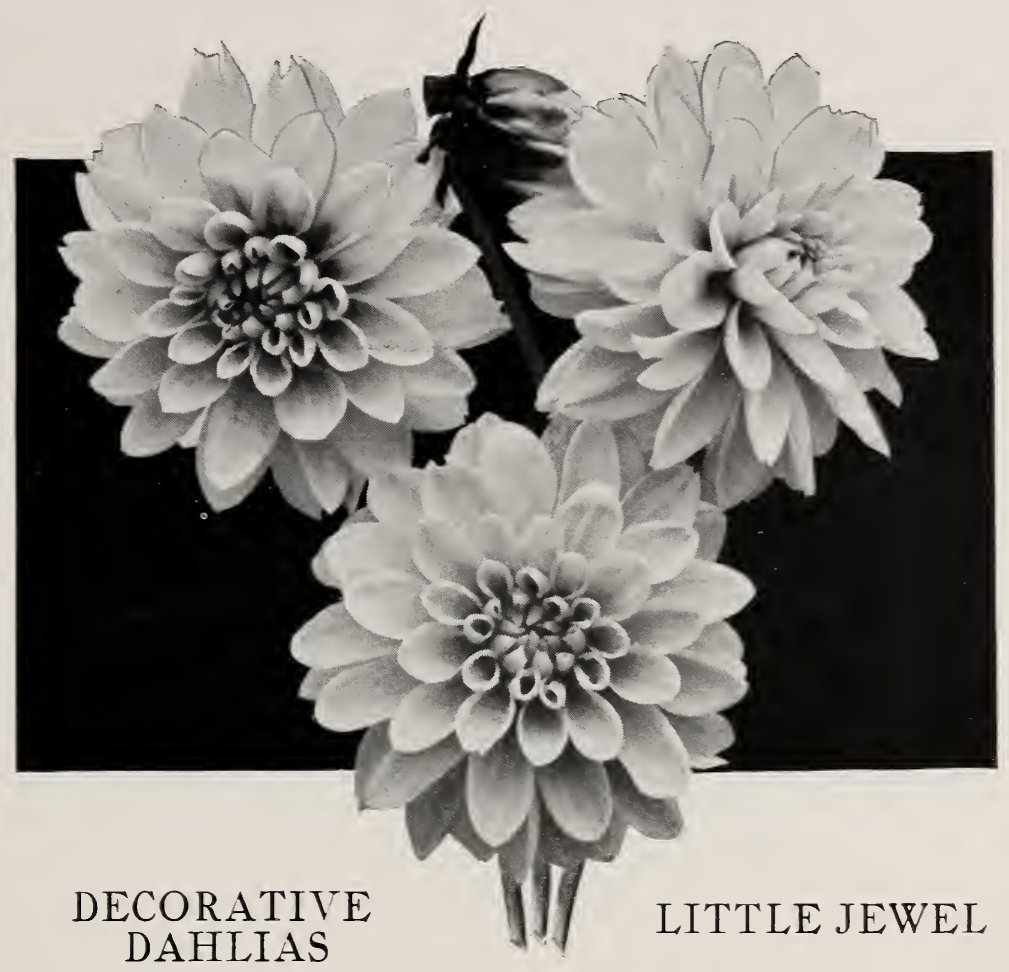

DELICE (Charmet)-Old but still good. A bright, yet soft, luminous pink. Flowers held facing well above the foliage.

GIANT RUBY (Greinberg)-Bright scarlet is always showy, and makes this dahlia attractive. A tall grower, flowers medium large on erect stems.

Tubers, $\$ 1.00$

LITTLE JEWEL (Papendricht) - In reality a miniature decorative. Popular for exhibition as well as a cut flower. Grows about two inches. Color, a pleasing peach blossom pink.

PINK FLAMINGO (Flamingo)-One of our best keepers as a cut flower. An occasional open center flower does not taboo the variety as a good profitable commercial flower. Color, violet rose overlaid soft Tyrian rose.

SOIL PREPARATION. The dahlia will grow and produce excellent results on a wider range of soils than any other flowering plant. It is not a matter of soil type, but one of soil preparation. The primary factor to consider in growing dahlias is that of drainage. which in sandy soils is well taken care of. but in heavy soils dig in and thoroughly mix a quantity of coarse coal ashes or peat moss to open up the soil.

As soon as the soil can be worked in the spring it may be further improved by a cover crop of oats and Canada field peas. Or, better still, sow rye in september or October. This green crop will do no harm during the late blooming season, will winter over, and should be turned under about two weeks before planting. This will add organic matter, supplying humus, and further adjusting soil conditions. If soil is poor, the oats or rye may be top dressed with stable or hen manure, the sooner after planting the better.

DIVIDING CLUMPS. It requires a little judgment to divide rahlia roots properly, as some varieties are more compact than others. The eyes will be found around the stem or crown, and never on the tuber itself, like a potato.. Hence a tuber without a piece of the crown is worthless. A division consisting of a good tuber with one good eye is all that is necessary, more are of no advantage. Large clumps should never be planted whole. 


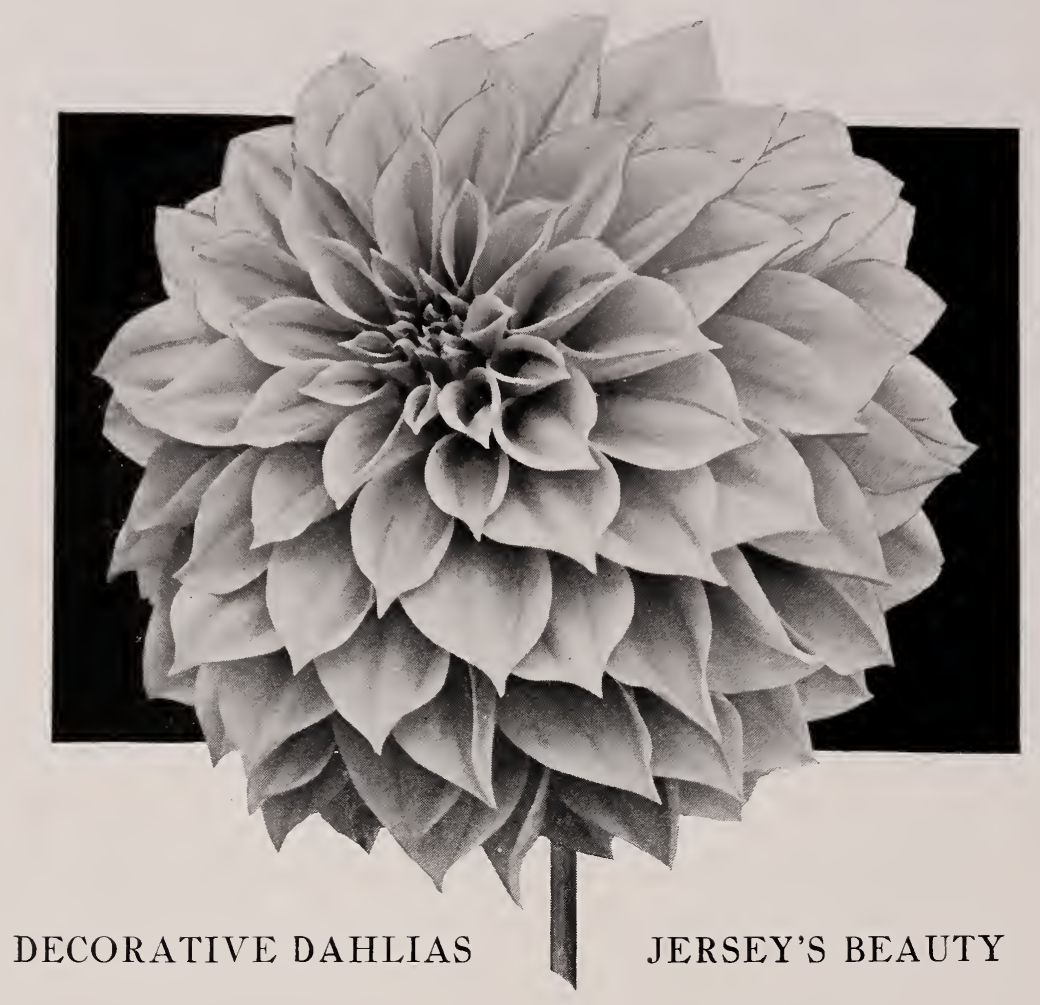

JERSEY'S BEAUTY (Waite)-Probably the most popular of any dahlia, the ideal pink for exhibition or florist use. Large deep flowers of perfect form on long stems. Free early bloomer with exceptional keeping qualities.

Tubers, \$1.00; Plants, .50

JERSEY'S GEM (Waite)-Large, well-formed flowers of lavender pink on long erect stems. A. D. S. Cert. of Merit and Silver Medal of the D. S. of N. J.

Tubers, $\$ 1.00$; Plants, .50

JOHN LEWIS CHILDS (Boston)-A good variegated dahlia. Color, yellow penciled and suffused bright scarlet, occasionally tipped white. Flowers large, borne profusely on good erect stems.

$\$ 1.00$

MARJORIE HENNESSEY (Seal) Decorative-An exceptionally lovely large dahlia of most perfect formation held on extra long, stiff stems high above the tall growing bush. Color is amber heavily suffused rose, lightening toward the center to a true amber, with tips of the unfolded petals rose pink, producing a very artistic effect.

Tubers, \$5.00; Plants, $\$ 2.50$

M. H. DE YOUNG (Boston)-Pure old gold with the center illuminated with a brighter shade. Large blooms are held high on stiff stems well above the foliage. An excellent autumn shade cut flower or exhibition variety.

Tubers, \$2.00; Plants, \$1.00

MILLIONAIRE (Stillman)-Clear violet mauve, shading to white at cinter, very deep and massive. Bush 3 feet.

MRS. CARL SALBACH (Salbach)-Although not as deep as Jersey's beauty, this dahlia is very similar in petal formation, stem, and keeping qualities, all of which are ideal. Color, lilac rose shading to white at base of petals, giving it a general tone of soft rose. 


\section{DECORATIVE DAHLIAS-Continued}

PRES. WILSON (Jones)-The most striking variegated dahlia we grow. Crimson carmine tipped white, a few flowers all red. Bush dwarf, flowers numerous on good stems. Its one fault a poor root maker.

Tubers, \$2.50, Plants, \$1.50

PRIDE OF SAN FRANCISCO (McWhirter)-Another bedding variety when grown naturally, but nice stems can be produced by disbudding. A beautiful combination of salmon pink, suffused soft rose, shading to gold at base of petals.

$\$ 1.00$

PRIDE OF STRATFORD (Meachen \& Sherman) Decorative-Very large blooms held erect on strong stems. Color cadmium orange, shading to light orange yellow at the base of the petals, the reverse rose doree.

Tubers, $\$ 5.00$; Plants, $\$ 2.50$

SAGAMORE (Kirby)--This new dahlia is a wonderful commercial and exhibition variety. Color, amber gold, elusively shaded with a warm salmon rose and orange buff. An open, strong grower with erect stems, good keeping qualities and of uniform large size.

Tubers, $\$ 2.00 ;$ Plants, $\$ 1.00$

SANHICAN'S PRINCESS (F. \& M.) Decorative-This fine dahlia is for those of artistic temperament. beauty rather than size, specially suited for cutting and indoor decorating. Color, true shimp pink. An early and profuse bloomer on stiff stems. Medium tall grower. Atwarded Cert. of Merit D. S. of N. J., 1925.

Tubers, $\$ 2.50 ;$ Plants, $\$ 1.25$

SENATOR BAIRD (Peacock)-One of the strongest and best growing rich deep red dahlias. Flowers large with full centers on strong stems.

Tubers, $\$ 1.00$

SHUDOW'S LAVENDER (Boston) - Silvery lavender with white shadings, of beautiful formation. Plants are tall and robust, producing immense flowers on long stems. A general favorite.

Tubers, \$1.50; Plants, \$1.00

VENUS (Marean) - This popular large flower, with slightly wavy petals of white shaded violet rose, is dainty in color effect. Stem, bush and habit of growth make it very desirable. Early and profuse.

WATCHUNG SUNRISE (Smith)-This fine variety differs from the accompanying illustration as the petals are longer and somewhat curled or twisted. In color it is a golden amber, with the reverse of petals showing rose pink and each petal distinctly edged rose pink, making it very distinctive. Flowers are massive on strong erect stems.

Tubers, $\$ 10.00$; Plants, $\$ 5.00$

WHITE GLORY (Alling) Decorative-This fine large white is an early and continuous bloomer. Flowers, well formed, full centered, on long erect stems. Certificate of Merit A. D. S.

Tubers, $\$ 2.50$; Plants, $\$ 1.25$

HOIT TO PLANT. Tubers should be planted in trenches or holes six inches deep, laid flat down (not on end) and covered with earth not over two inches in depth, filling in as the plant develops. Do not plant the roots in or over any quantity of com. post or hot manure. The rows should be from four to five feet apart and the plants in the row from two to three feet apart, or from six to ten square feet should be allowed for each plant. A novel way to plant is to place your stakes $4 x 5$ feet apart. and plant a tuber or plant on each side of the stake giving you room to walk between and care for your plants, and also get as many in a given area as if planted twice as close. Different varieties will not mix by growing them together. Also should one plant fail there will be no blank places.

CULTIVATION. By cultivating at least once a week, and as soon after a rain as the ground can be worked, the weeds will be held in check and a soil mulsh formed which will conserve the moisture and lessen the need of irrigation.

As the plant develops and the feed roots come touard the surface, the ground should be worked rather shallow around the hill for the radius of at least a foot. still work the balance of the ground rather deep, and bring some fresh soil to the plant at each cultivation. giving the plant a new supply of food and protecting the surface roots from the heat of the sun. Have the hills mounded five or more inches by the middle of September. This will help support the stallis.

IRRIGATION. When your dahlias need water soak the ground at least a foot deep, then cultivate as soon as sufficient drainage has taken place, and do not water again until necessary, which will be a veek or more.

Do not spray your dahlia bushes, and sprinkle the surface of the ground every night or so, for this will only pack the surface, preventing air circulation and causing the soil to crust and dry rapidly in the sunshine. This also draws the feed roots to the surface, to be sickened by the heat of the sun's rays. The flowers obtained are soft, and the root development very poor, low in vitality, and hard to winter. 


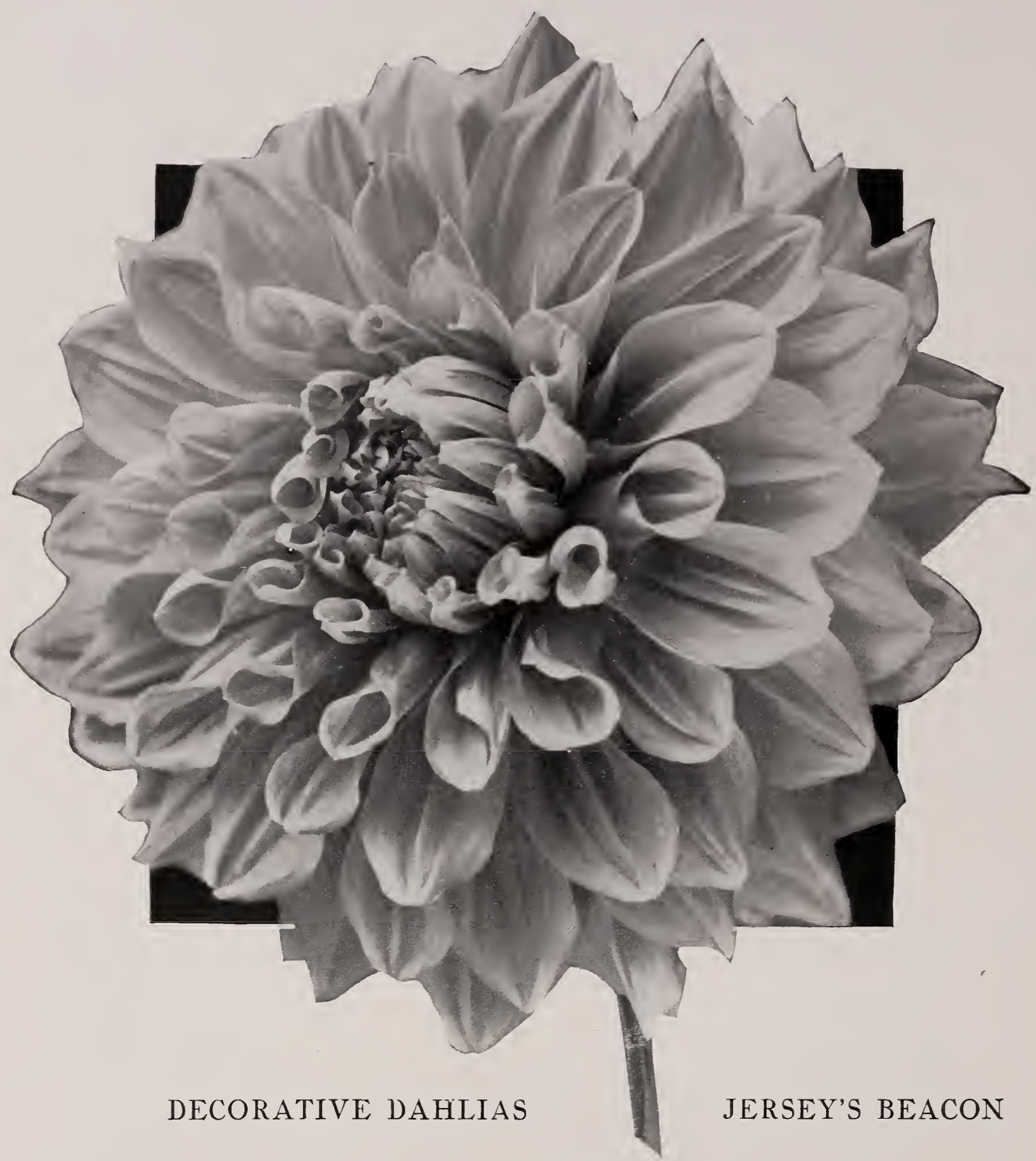

BASHFUL GIANT (Marean)-Well named for it is a flower of unusual size and although held on a strong stem faces partially downward. Color apricot with golden suffusion and shadings.

.75

EASTERN STAR (Dahliade1)-The color reproduction on the inside back cover can not portray the lively tones of this wonderful dahlia but does give you a general idea. Color a saffron yellow with old gold shadings. Flowers of great substance and good keeping qualities, with full centers held on strong erect stems. Excellent bush growth and free flowering. Grows ten inches without forcing. Eastern Star has a wonderful prize winning record and will be a real winner for years to come. It is one of the finest exhibition dahlias you can grow. D. S. of N. J. Cerit. of Merit.

Tubers, \$3.00; Plants, $\$ 1.50$ 


\section{DECORATIVE DAHLIAS-Continued}

EL DORADO (Boston)-An all purpose dahlia. Pure gold, deepening at the center. Immense flowers held well above the foliage on good stems. A profuse and early bloomer.

Tubers, $\$ 2.00$; Plants, $\$ 1.00$

ELIZA CLARKE BULL (Boston)-The largest white decorative from the West. A free bloomer of perfect form, and good substance that does not burn in extreme heat. Bush of medium height. A desirable variety for every garden.

Tubers, $\$ 4.00 ;$ Plants, $\$ 2.00$

JACK O'LANTERN (Reed) Decorative-A bright spot in the garden. Petals are wide open, a brilliant orange-red shading to a dark Spanish red near the center. The petals that form the center are tipped with gold making the general effect very bold and brilliant.

Tubers, \$7.50; Plants, $\$ 3.75$

JERSEY'S BEACON (Waite)-The most spectacular of the Jersey Family. Color bright scarlet, with a buff reflex giving a two toned effect. A free early bloomer of extremely massive proportions with sturdy stems.

Tubers, \$2.50; Plants, $\$ 1.25$

MARTHA WASHINGTON (Chester- Dahliadel)-A popular large full centered decorative dahlia. Very similar in form to Eastern Star. Color rich velvety maroon with a lighter reflex and tipped Tyrian rose. A very striking combination. Excellent stems and bush growth.

Tubers, $\$ 1.00$

PAUL REVERE (Bissell) Decorative-This fine red dahlia does not fade or burn in the strongest sunlight. Petals are a rich, bright velvety-red and look as though faintly touched with black. Large in diameter and deep, wavy petals. Excellent stem and growing habits.

Tubers, \$3.50; Plants, $\$ 1.75$

QUEEN OF THE GARDEN BEAUTIFUL (Burns)-This distinctive and interesting dahlia originated in the famous garden of the San Quentin Prison. An immense primrose yellow facing upward on strong stems. An occasional bloom has a green center but it is so massive that we easily overlook the imperfection.

Tubers, \$7.50; Plants, $\$ 3.75$

ROBERT SCOTT (Brock)-This fine new dahlia is of a bright apricot yellow with shades of rose. Flowers are large and deep of good form on excellent stems. The bush is of stocky growth about 4 feet tall.

Tubers, \$5.00; Plants, \$2.50

ROBERT TREAT (Muehler)-This dahlia, similar in color to the American Beauty Rose, is different from any other dahlia in shade or color. Plants are strong, healthy growers of spreading habit. Flowers from 9 to 10 inches and 4 inches deep, produced on long, erect stems.

Tubers, \$1.50; Plants, $\$ 1.00$

BRANCHING. Allow only one stalk to grow (never more than two). Pinch out the crown or centre above the second pair of leaves or eyes. The principle of taking out the center is to develop the eyes, which are located at the base of the leaves between the stem and leaf. The top pair of eyes will make themselves evident in surprisingly short time, and these shoots or laterals on most varieties should be pinched back again, leaving one pair of eyes on each branch. By the time these get a start the second or lower set of eyes on the main stalk will have developed along with the four above. These six stems should bear the first six flowers.

DISBUDDING. When the terminal bud on each of these stems is about the size of a small acorn, or as soon as the side shoots are large enough to pull out, disbud by taking out all the side buds and shoots except the lower pair on each of the six branches. Leave only one side shoot on each, should you desire very large flowers. These new branches should be handled as the previous set. Alh of the disbudded stem should be cut with the flower. This early disbudding and pruning is not solely for the benefit of the first six flowers, but mainly to keep the bush low and properly branched for the future crop.

Certain varieties branch to excess. These should be thinned out at intervals of two weeks, and not more than six shoots allowed to come into bloom for the first flowers. This affords the plant better air circulation and sunlight. 


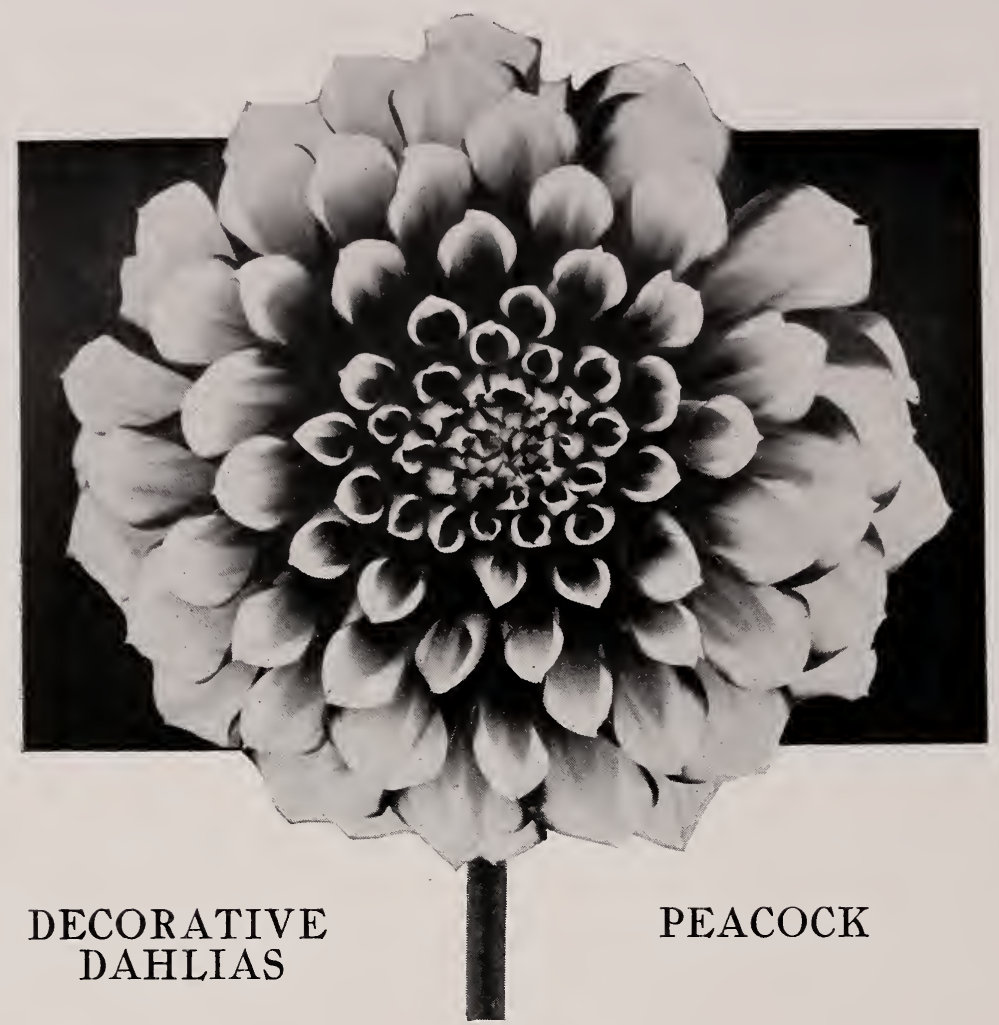

BEATRICE SLOCOMBE (Slocombe)-Large, brilliant crimson red with golden suffusion and tips. A good grower and bloomer. Very showy.

CHARM (Marean)-A much admired autumn shade of burnt orange shading to yellow. Particularly suitable for decoration with autumn leaves. Flowers large and evenly formed.

.75

D. M. MOORE (Wilmore)-Rich, dark, velvety maroon, almost black. The most popular dark dahlia. Bush of medium height. Early and profuse.

.50

ELSIE JANE (Schmidt-Dahliadel)-This variety did not come up to our ideals as the stem was not always strong enough to hold the flower erect, owing to the wet weather last season causing such a rapid growth. It is, however, such a beautiful color for a garden flower and proved so satisfactory as such where grown for trial, that we are going to introduce it at $\$ 5.00$ each instead of $\$ 10.00$ as first planned. Flowers are of good size with full centers. It is a healthy, vigorous grower and prolific bloomer. Color, pale lilac rose shading to white at the center and distinctly tipped with bright violet mauve.

Tubers, \$5.00; Plants, \$2.50

FLORENCE FINGER (Finger)-A garden variety that grows to exhibition size. Color, bright rose pink. Bush rather compact producing strong erect stems.

.50

FRECKLES (Dahliade1)-Buttercup yeliow streaked and penciled garnet, some flowers all garnet. Early and very profuse bloomer. A. D. S. Certificate, 1920.

GLORY OF ARGONNE (Dahliade1)-Color, delicate violet rose shading to white at center. Perfect, even form. Fine for garden or exhibition.

THRIPS are tiny insects that enter the growing tip or shoot and chafe the newly formed leaves injuring them so that they develop malformed and curled. These insects seem to enjoy the life blood of certain varieties on account of its flavor and do not molest the adjacent bush. If the attack is not checked it will result in a stunted bush which in reality is only debilitated by insect ravages. 


\section{DECORATIVE DAHLIAS-Continued}

HARVEST MOON (Dahliadel) -A wonderful dahlia, bush dwarf, with large flowers held well above the foliage on stout stems. The broad, thick petals curve back towards the stem, almost making a ball; color, a clear, deep sulphur or primrose yellow. A. D. S. Certificate, 1920.

JEAN KERR (Burpee)-This white dahlia of medium size is always in bloom. Bush compact. Flowers well above the foliage on good stems. Fine for bedding and a good keeper for cutting.

LADDIE (Broomall)-An excellent dahlia for exhibition or cutting. Large, well-formed flowers of wonderful substance on rigid, erect stems. Color, soft sulphur yellow at center, shaded and suffused rose and tan. A dahlia of real merit.

LA GROSSE BETE (Marean)-Enormous flowers of a cerise color, held on strong stems. A strong grower and splendid exhibition variety.

LE GRAND MANITOU (Charmet)-A giant of excellent form; color, Bishop's violet mottled and striped French purple; some blossoms self-colored. Compact growth, bush 3 feet.

OREGON BEAUTY (Gill)-Intense Oriental red, carmine suffusion. A large standard variety. Stems not erect; fine for bedding.

OYSTER BAY BEAUTY (Chemar) Decorative-Dark velvety red always seems to be in demand to contrast with the lighter colors. In this new dahlia we have a fine large artistically formed, full centered flower on long erect stem. Scored 84 at A. D. S. Trials.

Tubers, $\$ 3.00$; Plants, $\$ 1.50$

PEACOCK (Peacock)-The finest variegated dark red and white we have ever seen or grown. Bush dwarf with large, deep flowers borne erect well above the foliage. Flowers of even form with full, deep centers, Evenly marked as much white as reddish purple, a characteristic uncommon in variegated dahlias.

Tubers, \$2.50; Plants, $\$ 1.25$

SAMMIE (Dahliadel)-One of the largest ball-shaped yellow decorative dahlias grown. Color, clear deep primrose yellow; of good substance. Bush 5 to 6 feet.

SHELIKOFF (Tyler)-One of the best dark dahlias for your garden. Large well formed flowers of good substance on erect stems. Color, deep garnet. A. D. S. Certificate, 1920.

STANLEY (Dahliadel)-A dark carmine purple shaded deep Tyrian rose, of perfect form and large size. A. D. S. Certificate, 1920.

WINFIELD SLOCOMBE (Slocombe)-This fine decorative dahlia is a beautiful burnt orange shading to gold at the center, an alluring combination for decorative purposes under artificial light. Good stems, and in bloom from early until late.

Tubers, $\$ 1.50$; Plants, $\$ 1.00$

LEAF HOPPERS are larger than Thrips and of a pale yellowish green color, a little over $1 / 8$ of an inch in length. They fly when the bush is touched during the heat of the day. These sucking insects do much to keep a plant from getting a good start. They, as well as Thrips and Aphids are common carriers of virus diseases and should be kept in control for this reason if for no other. During the windy weather when dust cannot be applied to advantage, overhead sprinklers used during the heat of the day will control red spider and check the Leaf-Hoppers and Thrips.

We believe the best control of Thrips, Leaf-Hoppers and Aphids is by dusting with a good nicotine dust. Apply in sunshine with the temperature above to degrees at weekly intervals from the time the plants are set or tubers start to grow as a preventive, and if any should appear, then about every 4 days until they disappear. By starting before their presence it is doubtful if you will see any. As it is diffcult to procure nicotine dust in most localities we are listing it on page 36 of this catalog.

STEM BORER. This black and white striped worm enters the stem above the ground and usually works upward and will be noticed in the early season by the shortening of the internodes, later on by wilting. Cut the plant off near the ground and get the borer with your knife. If the borer is below where you want to cut back, use a hooked wire from the top. A plant cut back not later than July 15th should be in full bloom early in september. 


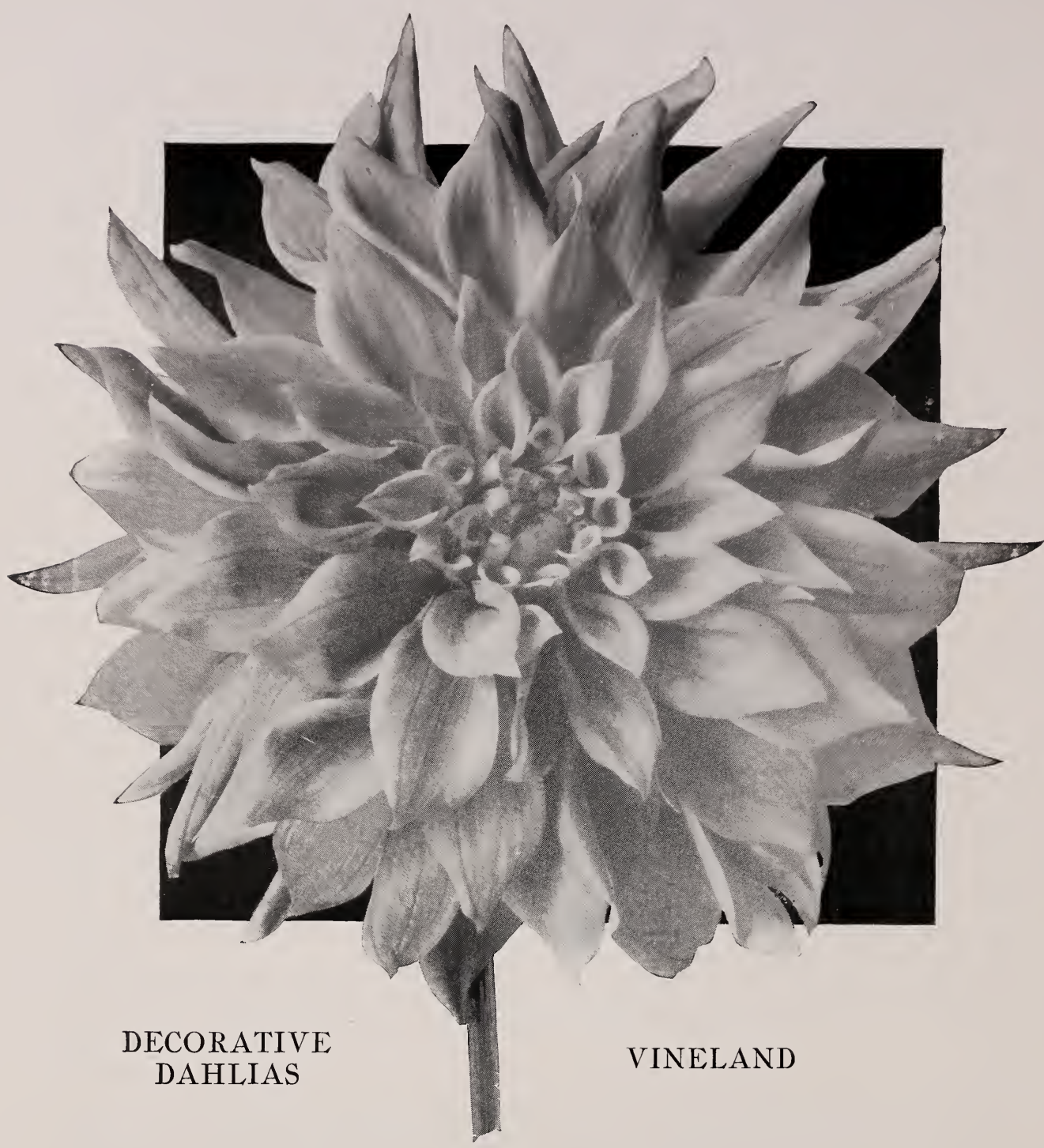

AMARILLO GRANDE (Broomall)-One of the large light yellow dahlias often found on the exhibition table. The flowers are well formed and held on strong erect stems. Bush 4 to 5 feet.

Plants, \$2.50

COLOR SERGEANT (Hall)-This striking variety scored 87 at the D. S. of N. J. Trial Grounds and is becoming very popular. Color is unusual, being a rich deep salmon bronze of one shade. A strong upright grower with perfect stems. Plants, \$3.75

DOROTHY ROBBINS (Finger)-Color, peach red suffused apricot. A fine grower of very good form, flowers average 6 to 8 inches. As a cut flower it is one of the best keepers.

F. A. KENT (Fisher \& Masson) A pleasing exhibition decorative of the stag-horn type. A beautiful mallow pink with rigid stems that hold the flower well above the dark green foliage. D. S. of N. J. Certificate of Merit.

Tubers, $\$ 2.00$; Plants, $\$ 1.00$

GRANDOLA (Broomall)-This dahlia is very attractive, its color being a brilliant golden orange. The blooms are of medium size held erect on fine stems making a desirable cut flower. Bush from 5 to 6 feet.

Plants, \$2.50 


\section{DECORATIVE DAHLIAS-Continued}

HATHOR (Seal)--Decorative-A dahlia of vivid coloring, not red but soft flame shading to lemon yellow at the base of each petal. Blooms are large with pointed petals and artistic formation, on erect stems.

Tubers, \$5.00; Plants, \$2.50

ISALM PATROL (Davies)-The popularity of this unusual dahlia is due to its striking coloring. A very dark velvety scarlet tipped and flushed pure gold. Flowers large and well formed on good erect stems, keeping well when cut.

Tubers, \$2.00; Plants, $\$ 1.00$

JERSEY'S FIANCEE (Waite)-This good sized flower is rose pink with the point of each floret slightly tipped gold, on erect stems. This variety proved very satisfactory for us last season. Awarded A. D. S. Cert. 1925. Tubers, \$5.00; Plants, \$2.50

JERSEY'S MONARCH (Waite)-A tall growing variety, flowers very large and deep on good stems. Deep salmon with yellow at the base of petals.Tubers, $\$ 2.50$; Plants, $\$ 1.25$

LADY LYNDORA (Hall)-This lovely dahlia is bound to become popular especially in the pink class as it is a pure pastel pink, with formation, size, and stem, to carry it through. Bush growth semi-dwarf with exceptionally free blooming habits. Plants, $\$ \mathbf{3 . 7 5}$

MEPHISTOPHELES (Marean)-Although not a profuse bloomer this variety produces large perfectly formed flowers on rigid stems. Color, rich carmine slightly tipped yellow.

$\$ 1.00$

MINA BURGLE (Burgle)-Rich, dark scarlet or geranium red; profuse bloomer; ideal for the garden or as a cut flower. Tall erect grower.

.35

MRS. ELEANOR MARTIN (Pelicano)-A very striking decorative that gives satisfaction wherever grown. A peculiar rose shade with reverse of violet, well described as "Mulberry." A profuse bloomer with good stems. $\quad$ Tubers, $\$ 3.00$; Plants, $\$ 1.50$

MRS. F. A. C. PERRINE (F. \& M.) Decorative-Another exhibition dahlia of the stag horn type. Petals curiously curled and twisted, terminating in sharp points. Flowers 8 to 10 inches across on long stiff stems. Color, a lovely shade of lilac.

Tubers, \$3.50; Plants, $\$ 1.75$

PATTY JANE (Seal) Decorative-Large blooms on long, fine erect stems of a lovely delicate mauve with lighter shadings. It is excellent for cutting and exhibiting and a seedling of Mrs. Carl Salbach with all its good qualities.

Tubers, \$2.00; Plants, $\$ 1.00$

PRIDE OF DAHLIADEL (Dahliadel)-We hesitated introducing this variety as it is similar in general color to the Grizzly. But in all tests it has proven so much more satisfactory that we now heartily recommend it. Full centered flowers produced on strong healthy bushes. Color, rich deep non-fading carmine red.

$\$ 1.00$

ROMAN EAGLE (Fisher \& Masson)-This popular 1926 introduction is an uncommon a utumn shade decorative of a brilliant burnished copper. Scored 89 at the D. S. of N. J. Trial Grounds. A real winner.

Tubers, \$3.00; Plants, $\$ 1.50$

SANHICAN'S GEM (Fisher \& Masson)-A favorite decorative of old rose suffused with amber, maturing into a delightful clear old rose with a glistening sheen. Staghorn type with the petals long and thickly placed. D. S. of N. J. Certificate of Merit, 1925.

Tubers, \$2.50; Plants, $\$ 1.25$

SANHICAN'S MONARCH (Fisher \& Masson)-A popular decorative dahlia that is much admired for exhibition. Color, deep Tyrian rose at center of flower, shading to lighter tones at tips. A free bloomer on excellent stems, and good keeping qualities.

Tubers, \$3.00; Plants, $\$ 1.50$

SUN MAID (Edymel) Hybrid Cactus-A glorious orange red and gold dahlia of unusual size and perfect form, giving you an abundance of deep blooms on long stiff stems, during the entire season. A prize winner in the West. Tubers, $\mathbf{\$ 5 . 0 0}$; Plants, $\mathbf{\$ 2 . 5 0}$

VINELAND (Dahliadel)-Since introduction this dahlia has made many friends. The bushes are strong and healthy of medium height, producing an abundance of large flowers of that popular fall shade, russet orange suffused apricot.

$\$ 1.00$

WM. SLOCOMBE (Slocombe)-This dahlia will appeal to you for size. Color, clear, canary yellow. Stems not pendant but not always strong enough to hold such massive blooms erect.

$\$ 1.00$

CUT WORMS are easily controlled by scattering about a teaspoonful of poison bran. bait around the plant (but not touching it) as soon as plants are set or shoots appear from tubers. The early evening is the best time to apply it.

2 tablespoonfuls of molasses or brown sugar.

1 level teaspoonful paris green mixed in.

Juice of an orange or equivalent in water.

1 quart of bran or ennugh to make a reasonably dry mash. 


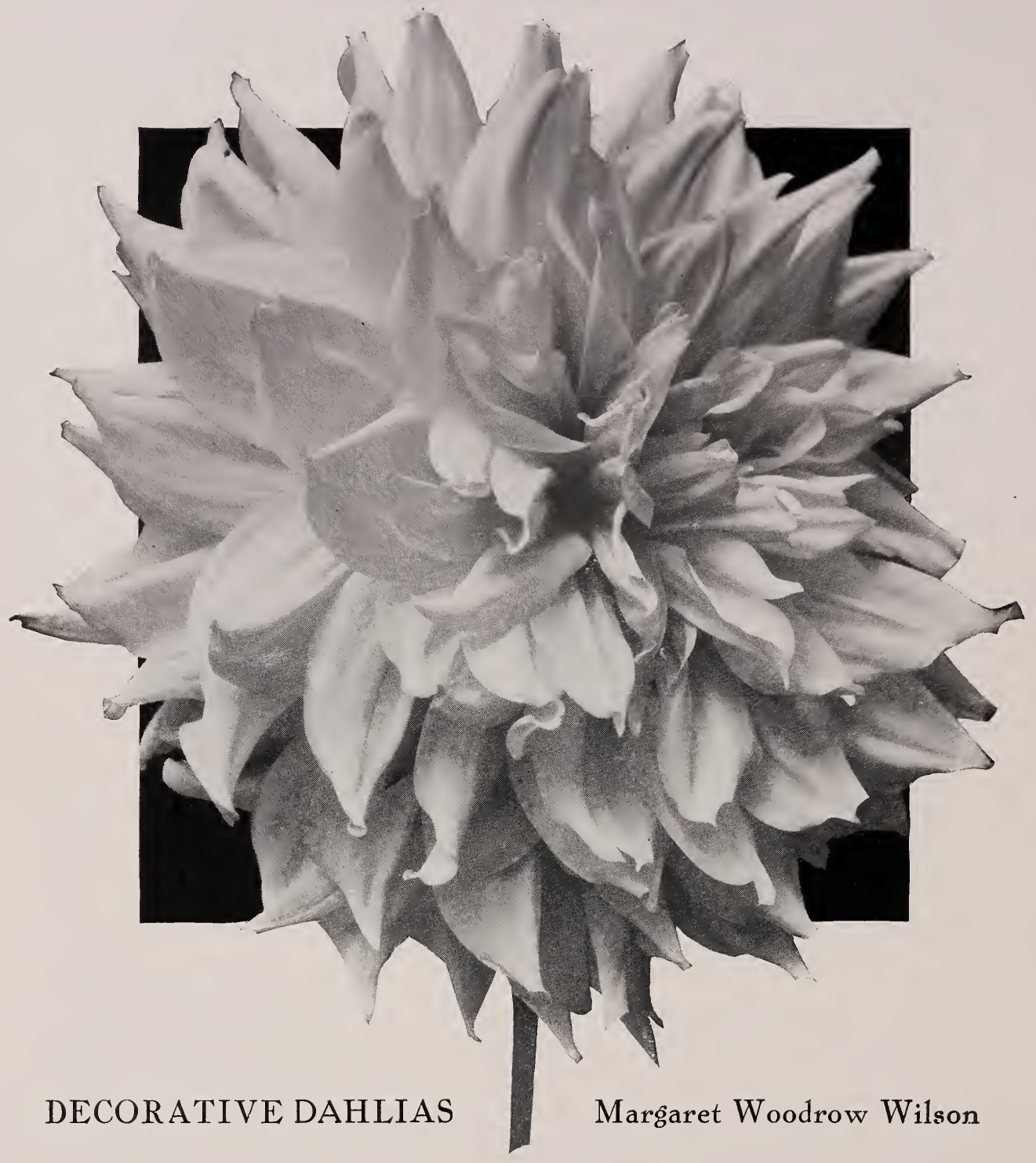

ALTAMONT (Kemp) Decorative-Large, full flowers, average 8 inches across, with long slightly curved petals giving the blooms an artistic form. Plants of a tall growing habit, with long slender but rigid stems. Flowers are good keepers and enough different from anything else to appeal to you. Color, rose pink, deepening to American Beauty rose at the center of the flower.

Tubers, \$5.00; Plants, $\$ 2.50$

AZTEC GLORY (Broomall)-We believe this to be the most spectacular yellow exhibition dahlia yet introduced. It is a clear picric yellow with deep massive flowers of unusual and most artistic formation held on strong erect stems. Bush about $2 \mathrm{I} / 2$ feet high with glossy green foliage having somewhat the appearance of holly. Plants, $\$ \mathbf{5 . 0 0}$

CHAS. STRATTON (Stratton)-A blue ribbon winner in the class for the largest bloom. Not only are the flowers large but deep and massive, keeping well when cut. Blooms early and profusely on strong erect stems. rose red.

Color, pale gold shaded and tipped Tubers, \$2.00; Plants, \$1.00 


\section{DECORATIVE DAHLIAS-Continued}

E. B. ROBERTS (West)-A striking autumn shade decorative with exceptional keeping qualities. Color old rose at base of petals overlaid apricot. A free blocmer on perfect stems.

Tubers, $\$ 1.50$

FORT WASHINGTON (Rindfleisch-Jost)-This is at present the best and largest dark red exhibition decorative. The bushes as well as the flowers are giants with long strong stems. Color dark mahogany red which does not fade. Tubers, $\$ 7.50$; Plants, $\$ 3.75$

JERSEY'S IDEAL (Waite)-We consider this one of the best of the Jersey's. The flowers are large, of great depth and held erect on strong stems. The bush is a vigorous grower with leathery leaves and grows about 3 feet. Color varies between a lavender and Phlox pink overlaid with a decided silver sheen. Tubers, $\$ 5.00$; Plants, $\$ 2.50$

JERSEY'S EMPRESS (Waite) Decorative-A large anthracene violet dahlia of pleasing formation, having narrow and wavy petals. Good depth and substance. Color is almost sunproof. Stem fair.

Tubers, $\$ 5.00$; Plants, $\$ 2.50$

JERSEY'S SOVEREIGN (Waite)-Similar in form to Jersey's beauty, but of a more compact growth. Flowers well formed on good stems. Color, salmon orange.

Tubers, $\$ 2.00$; Plants, $\$ 1.00$

JIM GEORGE (Murphy) Decorative-One of those different rich velvety dark red dahlias with enough twist in the petals to make it artistic. Blooms freely on good stems well above the foliage.

Tubers, \$3.50; Plants, \$1.75

MARGARET WOODROW WILSON (Fisher \& Masson)-An exhibition decorative of immense size and wondrous beauty. Color an opalescent pink. Face of petals creamy white with a phlox pink reverse. One of the very best 1926 Introductions. D. S. of N. J. Certificate of Merit, scored 86.

Tubers, $\$ 4.00$; Plants, $\$ 2.00$

MRS. JOHN T. SCHEEPERS (Marean)-Seen often on the exhibition table as this dahlia has size and good stems. Color, canary yellow with a pink suffusion on the outer petals.

Tubers, $\$ 1.00$

OUR COUNTRY (Stillman)-This deep full centered decorative, symbolic to its name is purplish red tipped white. Stem rigid but not erect.

Tubers, $\$ 1.50$

POP STEWART (Fisher \& Masson)-This giant decorative dahlia received a score of 90 at the D. S. of N. J. Trial Grounds. A wonderful grower on excellent stems. Pure lilac pink and one of the finest dahlias of its color. Tubers, $\$ 2.00$; Plants, $\$ 1.00$

SANHICAN'S BLUEBIRD (Fisher \& Masson)-A pleasing rear to blue decorative dahlia with outer petals of bright violet blue while the center petals retain the violet tint. A noble flower on wiry stems.

Tubers, \$2.00; Plants, $\$ 1.00$

SANHICAN'S MAGNATE (Fisher \& Masson)-A splendid exhibition decorative of a pale amaranth pink, face of petals tinged with a deeper shade, and the reverse of petals a solid claret color heavily veined. One of the "big fellows." Awarded D. S. of N. J. Certificate of Merit, 1925.

Tubers, \$4.00; Plants, $\$ 2.00$

SUSAN G. TEVIS (Boston)-This variety trends to the blue tones but is a bright, rich lilac with blush sheen. This variety is a rigorous grower producing large, perfect blooms on fine stems through the season.

Tubers, $\$ 2.00$; Plants, $\$ 1.00$

WORLD'S BEST WHITE (Murphy)-As fine a white for exhibition or garden as you could choose. The immense creamy white blooms are born profusely on stiff stems.

Tubers, $\$ 2.00 ;$ Plants, $\$ 1.00$

ZEUS (Peacock)-Gigantic blooms on stiff stems. Color is a rich glowing red, each petal distinctly tipped yellow. So artistically and richly colored that it attracts. Plants 3 to 4 feet high, strong, sturdy, and healthy. A free and continuous bloomer.

Tubers, \$5.00; Plants, $\$ 2.50$

Dont use nitrate of soda as a fertilizer. Don't try to grow exhibition blooms by forcing the life out of your stock with sheep or any other manure, without balancing your plant food with phosphoric acid and potash.

STONT. This in most cases is the result of the ravage of insects such as Leaf-Hoppers, Thrips and Stem Borers. Stunt caused by the rotting of the feed roots may be due to heavy rains or excessive watering where there is poor drainage, or by a virus disease, something similar to Mosaic. The first symptoms are the rotting of the feed roots causing yellow mottling on the leaves and the plant in general to yellowo and stop growing. Regardless of cause, all stunt should be dug and destroyed. Our many years of this practice leaves us less than $1 \%$ to dig annually. 


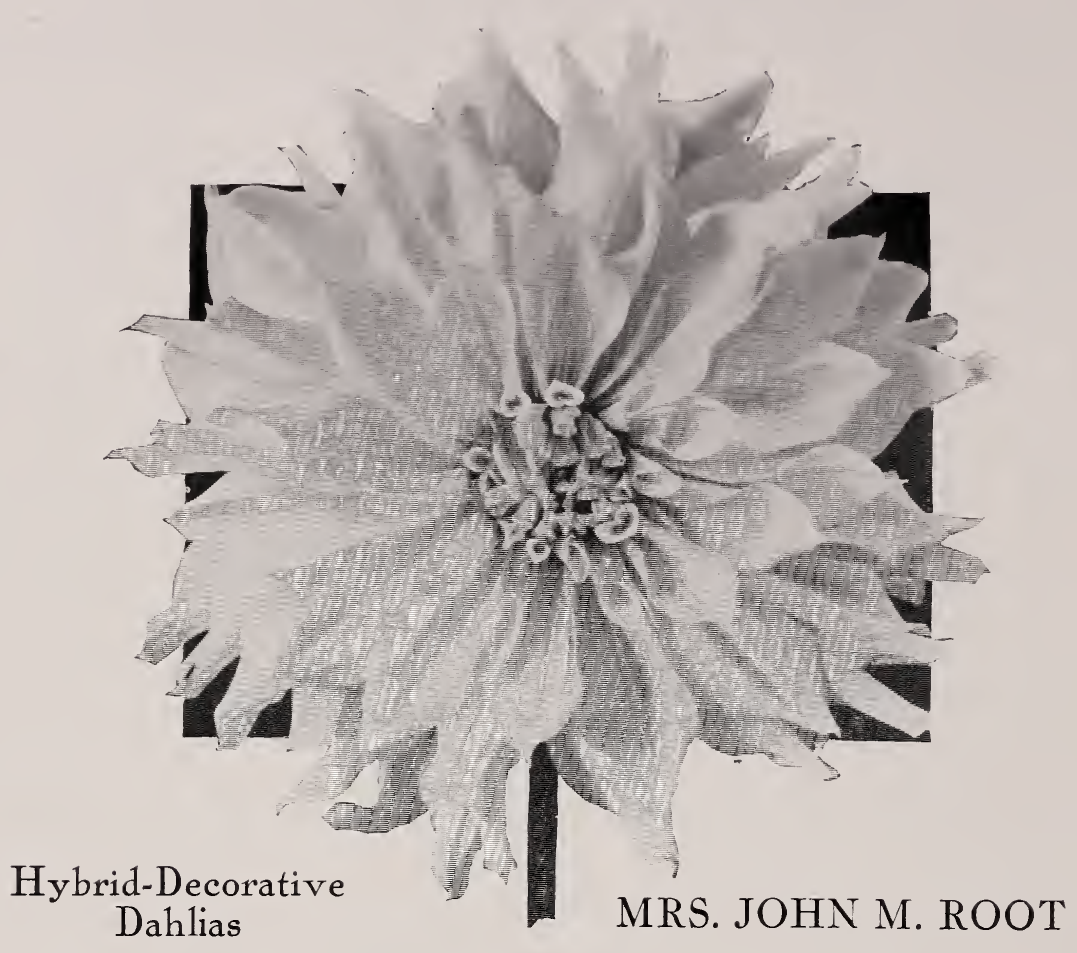

CITY OF LAWRENCE (Reed)-A strong growing variety giving a lot of color in your garden. Flowers very large and deep with full centers. Color canary yellow.

Tubers, $\$ 2.50$; Plants, $\$ 1.25$

COMSTOCK (Boston)_An immense yellow flower of great substance. Petals slightly fluted. A very satisfactory garden variety.

EAGLE ROCK BEAUTY (Broomall)-This fine impressive dahlia certainly is a pretty combination of pastel pink with ivory or creamy white center. Petals long and gracefully twisted. A pleasing garden and exhibition variety. Tubers, $\$ 10.00$; Plants, $\$ 5.00$

ELBERON BEAUTY (F. \& M.)-As its name indicates, a beauty, large exhibition flowers of soft apricot shading to a slightly darker tone towards center, borne profusely and held erect on long rigid stems making it an ideal cut flower.

$\$ 1.00$

EL GRANADA (Boston)-A beautiful vivid orange dahlia with creamy white tips. Petals twist and interlace, giving it a very artistic form. Long stems hold the flowers well out of the foliage. An abundance of blooms cover the bushes the entire season. A very attractive dahlia.

Tubers, \$2.50; Plants, $\$ 1.25$

ELSIE DREXLER (Boston)-Deep velvety maroon of huge size. Bush strong and stems good. A good garden variety, blooms early and continuous.

EVA COLE (Murphy)-The popular combination of red and gold. Exhibition flowers can be grown 10 inches in diameter on erect stems.

Tubers, \$5.00; Plants, \$2.50

HIS MAJESTY (Boston)-A lively scarlet dahlia of good size and form. A free bloomer which does not require much disbudding to obtain size.

Tubers, $\$ 2.00$

INSULINDE (Kriest)-Still one of the most artistic dahlias of distinct form with petals twisted and curled. Stems are two to three feet long, and flowers 8 to 9 inches across, mostly facing upward. Color, a rich saffron yellow shaded russet orange. 


\section{HYBRID-DECORATIVE DAHLIAS-Continued}

LA MASCOTTE (Boston)-Entirely distinct in formation and coloring. Large blooms of silvery white, while the reverse is reddish violet, with petals quilled on first opening. An incessant bloomer on good stems.

LA RODA (Broomall)-This beautiful new variety is an unusual silver rose pink with large well formed flowers held erect on strong stems. The formation is somewhat irregular with numerous petals at the center. Height 4 feet. $\quad$ Plants, $\$ \mathbf{1 0 . 0 0}$

MISS BRIDGETON (Venable)-Beautiful light pink with violet suffusion. A tall vigorous grower, stems slender and not always holding the flower erect.

Tubers, \$1.50; Plants, $\$ 1.00$

MRS. JOHN M. ROOT (Root)-Immense flowers of pure canary yellow. Petals are long, broad and slightly twisted. Rather shy bloomer for northern localities. $\$ \mathbf{\$ 1 . 0 0}$

MYRA VALENTINE (Mills)-This tall growing variety produces large golden bronze flowers on two to three foot stems. Fine for exhibition or cutting. Tubers, $\$ \mathbf{1 . 0 0}$

PAPILLON (Boston)-A mammoth flower which is much in demand. Described as an improved George Walters, which it resembles, although decidedly different in coloring. Beautiful old rose illuminated with golden lights.

Tubers, $\$ 1.50$

PAUL MICHAEL (Michael)-A large dahlia produced on a dwarf bush. Petals curled and twisted. Color deep buttercup yellow, shaded with old rose, making it an ideal exhibition dahlia. Flowers 8 to 10 inches, bush 3 feet. Stems fairly good. $\quad .75$

ROOKWOOD (Boston)-Pure bright cerise rose without the faintest touch of magenta. Immense flowers of good depth held aloft on splendid straight stems.

Tubers, \$1.50; Plants, $\$ 1.00$

T. A. LEONARD (Boston)-A dahlia well worth growing producing an abundance of blooms from early to late on strong stems. Color, deep cerise or bright carmine rose. Giant full centered flowers with peculiar wavy petals.

$\$ 1.00$

THE U. S. A. (Stillman)-Resembling Vineland in general form and size, although the centers run open after the first few blooms, which places it in the peony class. Petals artistically twisted and curled. Color a vivid orange.

$\$ 1.00$

TUT (Dahliadel)-This unique dahlia differs from the illustration by having blunt notched petals. Flowers face partly upward on sturdy stems. Color, rich velvety purple garnet with lighter reverse. Excellent habits of growth.

$\$ 1.00$

VALLEY FORGE (Greinberg)-This large, greatly admired dahlia is held on very stout and erect stems. Color, light purple lightly suffused white. Tubers, \$1.00

WIZARD OF OZ (Doolittle)-A rare shade of glowing amber pink, shaded salmon. A real exhibition giant of beautiful formation. Good sturdy grower.

Tubers, $\$ 2.00$; Plants, $\$ 1.00$

WONDERLAND (Bissell) Decorative-Flowers are of large exhibition type, deep velvety garnet purple, reverse light rosy magenta. Petals are twisted and curled, making a two toned effect.

Tubers, \$3.50; Plants, $\$ 1.75$

ZANTE (Boston) Hybrid Cactus-Color gold, heavily suffused with apricot pink, having a center of a deeper shade. Blooms are very deep and large with rolled petals tapering to a point, held erect on stiff stems. Zante produces fine full exhibition flowers throughout the season.

Tubers, \$3.00; Plants, $\$ 1.50$

\section{CUT FLOWERS}

Dahlias should be cut in the evening or early morning, removing the lower leaves and all of the buds if not disbudded. Immediately put in water in a cool, dark place to freshen.

Hot Water Treatment-Cut and freshen as above, then put stems in 1 to 2 inches of water almost boiling for 1 to 2 minutes, then place in deep cold water to cool. Flowers are then ready to ship by packing in a strong corrugated box lined with tissue paper. Fasten stems down by nailing a wooden strip in the center of the box or by tying down through the bottom.

Flowers when wilted can be freshened by cutting end of stem and placing in hot water as above. Repeat until flower is freshened.

The Hot Water Treatment will do wonders in making your exhibition blooms keep fresh after staging, but in all cases do not cut off the discolored end of stem unless you are again going to treat it.

The physical action of a cut flower is to take water up into the stem which evaporates through the flower and foliage. The slower this action of evaporation or transpir. ation takes place the longer the life of the flower. 


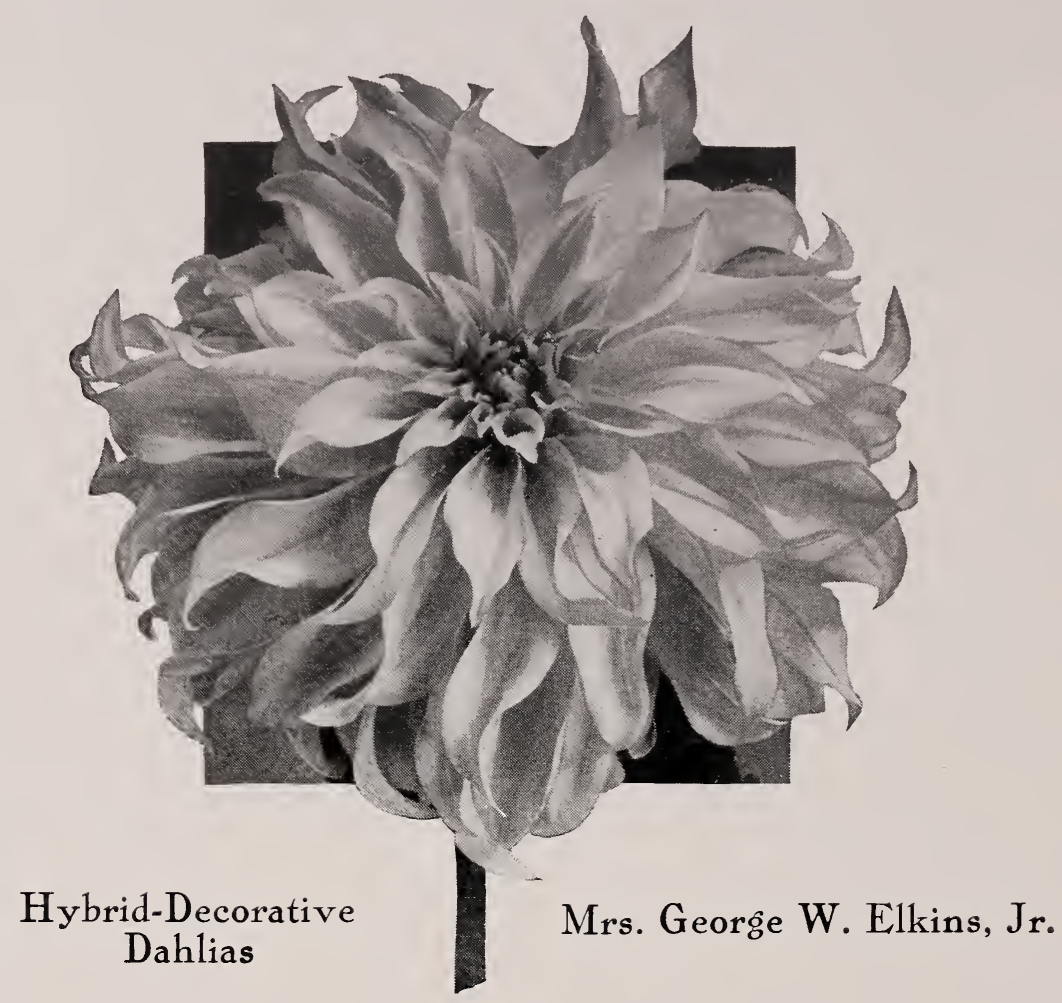

AUGUSTINUS (Ballego) - Large flowers with long petals which are more or less twisted. Color is a rosy salmon overlaid with bright metallic lilac. A very satisfactory dahlia. Vigorous bush grows 5 to 6 feet.

FLAMING METEOR (Baker)-This new dahlia is decidedly attractive owing to its unique form, bright color and good keeping qualities. The flowers have full centers and are borne in profusion on stiff wiry stems. Color deep cadmium yellow with scarlet suffusion at the center. The general effect being a flaming orange.

Plants, \$2.50

GOLDEN FLEECE (Seal) Decorative-Beautiful golden yellow with a satiny effect. Petals are often tipped white, which gives the dahlia a silvery appearance.

Tubers, \$7.50; Plants, \$3.75

GOLDEN JUBILEE (Star)-A delightful large, golden orange dahlia with good strong stem. Dwarf but very vigorous plant. A free bloomer exceptionally good for the garden or exhibition table.

Tubers, \$4.00; Plants, \$2.00

J. OTTO THILOW (Root)-Extra large blooms, are held very erect facing upward. Petals are long and pointed. Cardinal red without shading.

MARMION (Tyler) Decorative-A giant dahlia of lovely coloring. Pure golden yellow with a bronze center and reverse of petals reveals a bronze suffusion. The blooms are held on good stems well above the foliage of the sturdy plant. Good exhibition variety.

Tubers, \$7.50; Plants, \$3.75

MRS. GEO. W. ELKINS, JR. (Root)--The flowers are large and deep with full centers, borne on good stems. It is a free and open grower. The color is beautiful, old gold, suffused salmon pink with a faint reflex of rosy pink. Of remarkable beauty. A. D. S. Certificate, 1922.

$\$ 1.00$

JERSEY GROWN DAHLIA SEED-Grown and saved from the best and largest varieties in our own trial patch. Seed includes such varieties as City of Trenton and the best varieties listed in this catalog from pages 4 to 34 . with the exception of Poms and Singles. Our late season ripened a quantity of wonderful plump seed which too is "Potash Fed" and gathered before frost. California seed proved very satisfactory for us last year but our own gave us even finer dahlias and we feel sure will please you. 


\section{HYBRID-DECORATIVE DAHLIAS-Continued}

MRS. JAS. A. BABBITT (Root)-Flowers of immense size with incurved petals. Color, deep yellow with reverse of petals overlaid with crimson. A favorite commercial and exhibition dahlia.

RODMAN WANAMAKER (Peacock)-One of our strongest growing varieties, producing large flowers on long strong stems. Buds are a pale yellow, but as the flower expands, develops into a bronzy salmon pink. This variety has a real peony center which does not detract from its beauty.

Tubers, $\$ 4.00$; Plants, $\$ 2.00$

SANTA ANNA (Pelicano)-This fine variety is of an artistic formation with petals curled and twisted while the color is a beautiful salmon rose suffused with old gold. Plant is a good grower of medium height with large flowers held well above the foliage on good stems. Classified as a Hybrid Cactus in the West but very similar to the accompanying illustration for us.

Plants, $\$ 2.00$

SULPHUREA (Keynes)-The long narrow petals on this variety curve back to the stem giving the flower the appearance of a huge chrysanthemum. Color, soft sulphur yellow. Bush low branching and a wonderful bloomer.

THE BANDIT (Reed) Decorative-A wonderful scarlet red dahlia, the reverse of the petals a light carmine, of good size, on small wiry stiff stems. The petals are curled and twisted making it refined and artistic. An abundant bloomer with good qualities as a cut flower.

Tubers, \$5.00; Plants, $\$ 2.50$

THE GRIZZLY (Burns)-One of the most popular dark red decoratives grown. A giant exhibition variety. A prize winning novelty with long reflex petals. Color, velvety crimson maroon.

$\$ 1.00$

ALL VARIETIES ARE SIMILAR IN FORM TO THEIR ACCOMPANYING ILLUSTRATIONS.

AUTUMN CENTURY (Bassett)-Delicate madder lake, shading yellow at center. A beautiful autumn tint.

25

DAHLIADEL CENTURY (Dahliadel)-It is all that can be asked for in a white single dahlia. Its size, form, habit of growth, productiveness, and clear pure white color put it far ahead of anything else. .25

ECKFORD CENTURY (Peacock)-Large white spotted pink penciled crimson. An early free bloomer on good stems.

.25

SENSATION DUPLEX (Bassett)-Rich geranium or cardinal red, tipped pure white. Some flowers pure red. Very distinct and popular.

.25

TANGO (Dahliadel)-Cadmium yellow, shaded scarlet orange. A lively autumn tint.

\section{CENTURY OR SINGLE DAHLIAS}

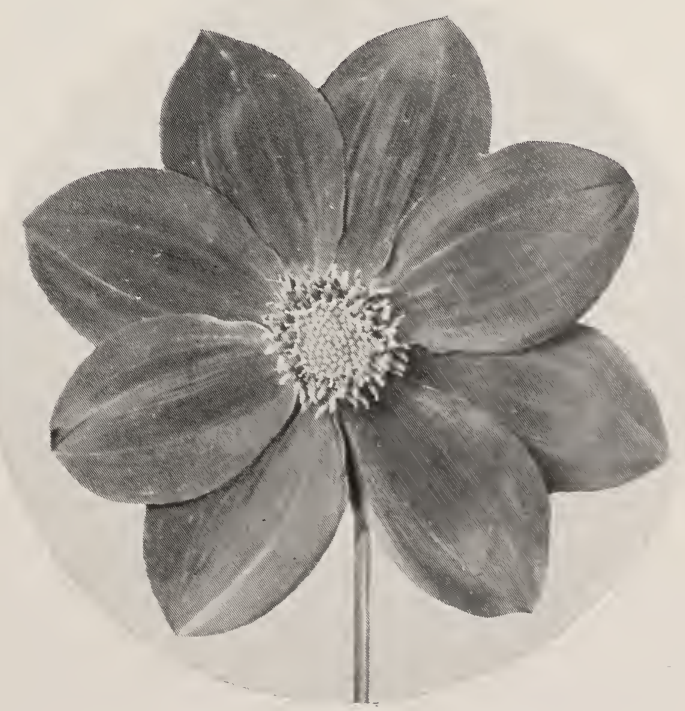




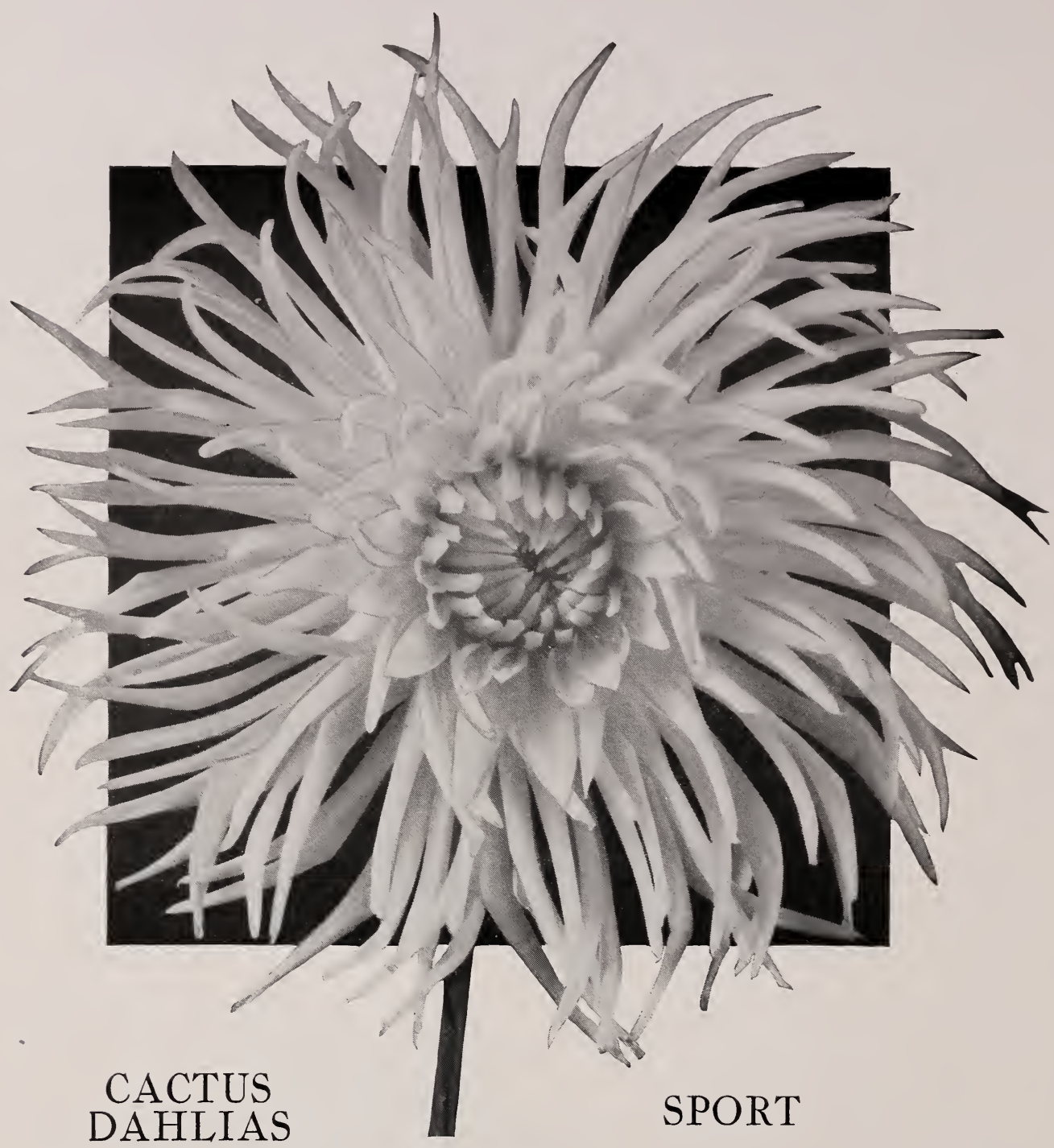

The dahlias in this group are commonly known as English Cactus. A characteristic of this type is a slender wiry stem not always holding the flower erect.

BALLET GIRL (Boston)-Beautiful flowers of immense size, color, orange tipped white, some flowers pure orange, with other variations on same bush.

F. W. FELLOWS (Stredwick)-Flowers of phenomenal size, composed of numerous long narrow petals of a lively orange scarlet. A good exhibition and commercial variety. .75

PIERROT (Stredwick)-This large French dahlia is very striking with its deep amber petals usually tipped white; a great exhibition variety.

SPORT (Dahliadel, 1926) - As its name indicates it is a sport of F. W. Fellows with all its merits, but a pleasing shade of deep buttercup yellow with buff shadings at center. Have grown this variety four years and it has never reverted to its parent A wonderful exhibition flower, and fine for cutting, also a favorite in the garden. $\$ \mathbf{\$ 1 . 0 0}$ 


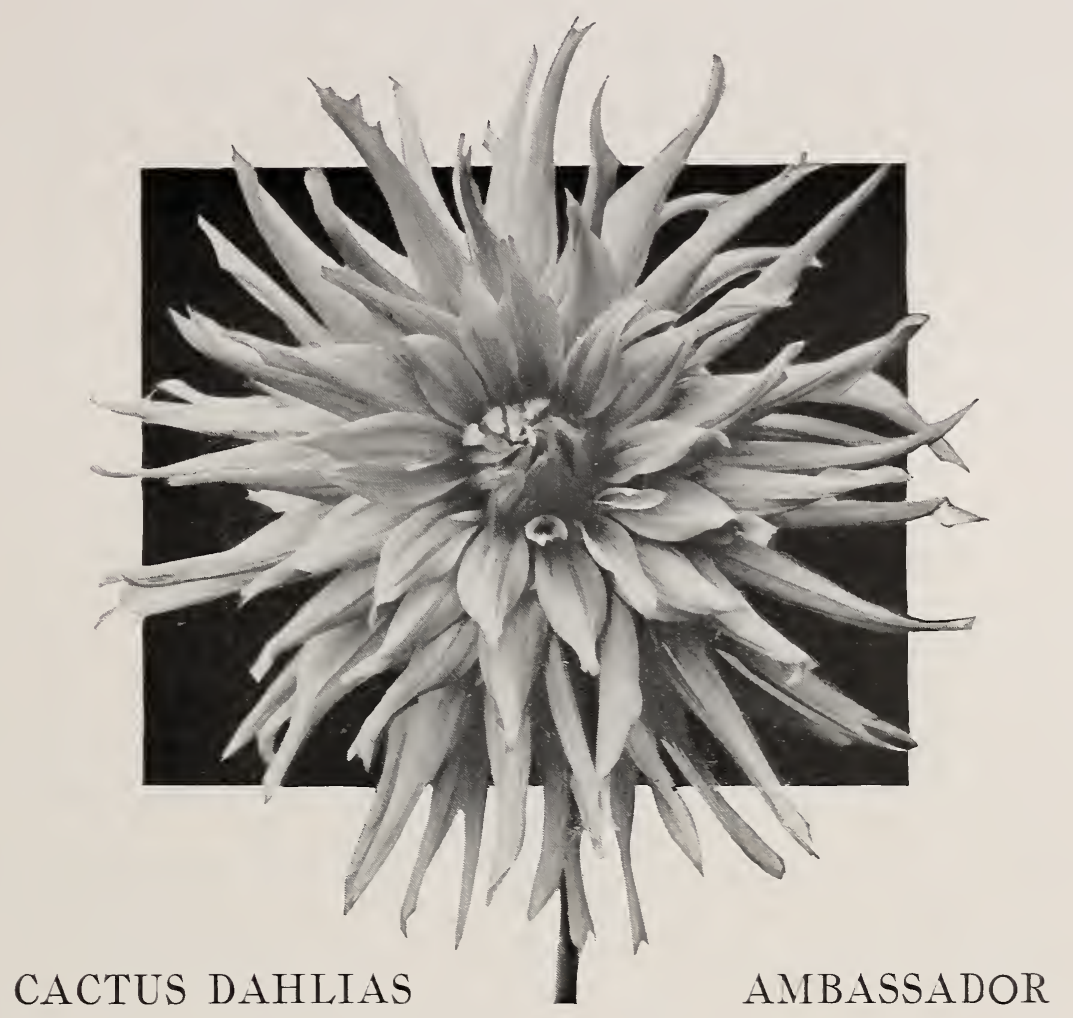

AMBASSADOR (Broomall)-In evidence at every danlia show is this fine exhibition and commercial flower of soft yellow buff shaded salmon pink. Well formed flowers, held erect above the foliage. Bush of medium height and branching habits.

Tubers, $\$ 1.00$

EAGLE ROCK SUNSHINE (Broomali) Cactus-This looks like the best yellow Cactus to date. Bush is of a fine growing habit, producing large, beautifully formed primrose yellow flowers on long, slender erect stems. A real exhibition dahlia with wonderful keeping qualities.

Tubers, \$7.50; Plants, $\$ 3.75$

MARGUERITE BOUCHON (Cayeux)-A dainty cut flower, center pure white, outer petals a brilliant, yet soft violet rose with distinct white tipping.

MIRAFLORA (Broomall) - Although this dahlia, owing to its light graceful formation, looks frail, it is a wonderful keeper when cut. Bush is rather dwarf with stems long and erect. Blooms grow 8 to 10 inches in diameter without disbudding. Color white tinted violet pink.

Tubers, \$5.00; Plants, $\$ 2.50$

MRS. E. F. T. SMITH (Broomall)-Immense flowers held well above the foliage on strong stems. Color, creamy white shading to lemon tint at center. Petals broader at the base than illustration. A sturdy grower.

SILVERADO (Seal) Hybrid Cactus-Immense blooms of white, gradually shading toward the center to a delicate silvery lavender. The stems are extra long and the well branched bushes are always covered with blooms. Tubers, $\$ 7.50$; Plants, $\$ 3.75$

SISKIYOU (Broomall)-Here we have one of if not the largest dahlia that grows. Flowers held erect on long strong stems. Color, pink tinted mauve. Petals rather blunt and flat.

Tubers, \$2.50; Plants, \$1.25 


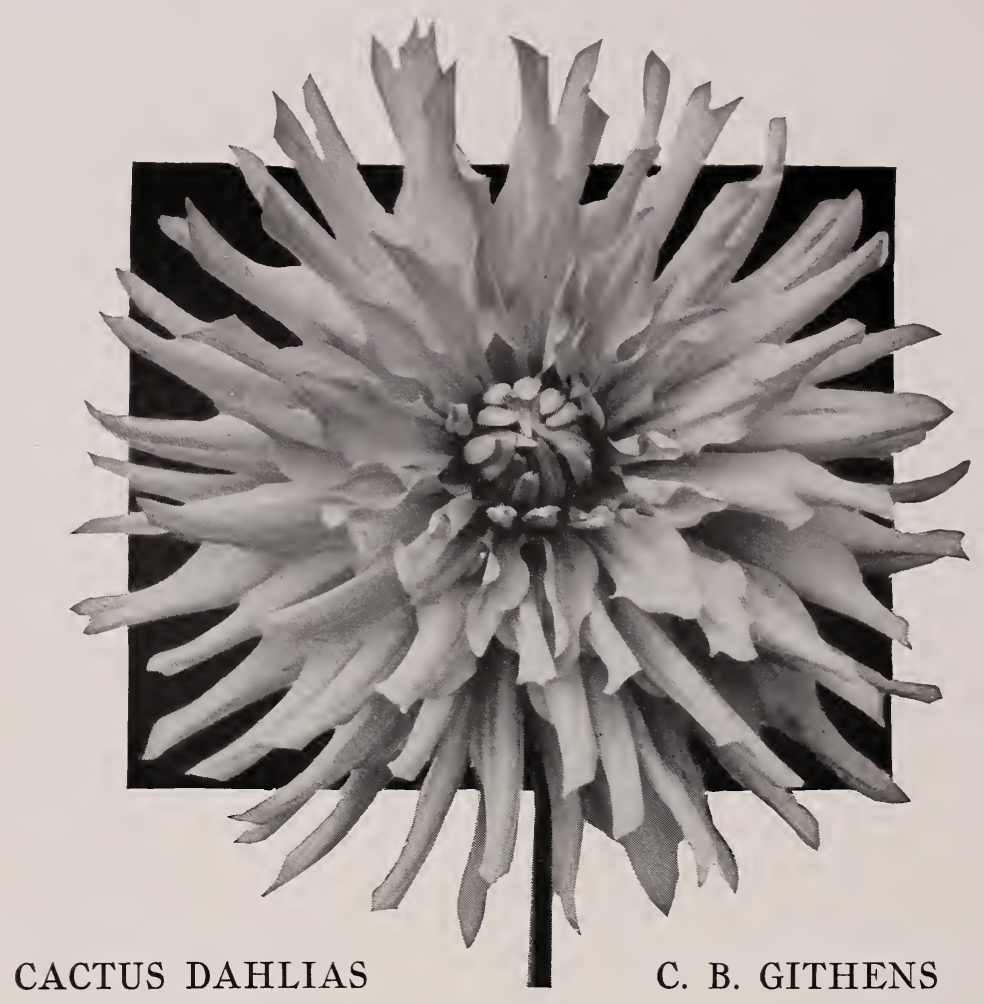

ADDA PATTERSON (Kemp) Hybrid Cactus-Although we have not tried this variety in the cut flower market, we believe it to be the best pure white Hybrid Cactus grown. Flowers are large, 8 to 9 inches across, of a splendid even form, on long, erect stems. A wonderful exhibition variety on account of its keeping qualities, along with its size, stem and form. Bushes 6 to 7 feet tall.

Tubers, \$5.00; Plants, $\$ 2.50$

CALIFORNIA BEAUTY (Broomali)-A pure copper in color. Much resembles Golden West Cactus, except better bush growth and much larger. A good cut flower.

C. B. GITHENS (Peacock)-One of the finest and largest clear yellow cactus dahlias we have grown. Produces well-formed flowers of good substance and keeping qualities on long, slender but stiff stems. Valuable for exhibition and as a commercial. $\$ \mathbf{\$ 1 . 0 0}$

ECLIPSE BEAUTY (Winzer) Cactus-Bright vermillion with base of petals, reverse and tipping of primrose yellow. Petals are supplemented with a small petal of the same coloring which twists giving an unusual effect.

Tubers, \$5.00; Plants, \$2.50

ESTHER R. HOLMES (Greinberg)-A wonderful orchid pink dahlia similar to Attraction in color, but of a much deeper formation, and holds a full center. Very satisfactory.

ETENDARD DE LYON (Rivorire)-Large, yet graceful blooms. Color, reddish violet overlaid Tyrian Rose.

FRANCIS LOBDELL (Waite)-Flowers large and of perfect form, mallow pink shading to white in the center. Wonderful free bloomer, splendid bedding variety, as well as exhibition. 


\section{CACTUS DAHLIAS-Continued}

IAN (Boston) Cactus-A giant of the incurved English type with heavier petals. Unusual coloring and exceptionally good form. Very clear yellow flower, gradually shading to pink on the outer petals. The reverse of these petals reveals a golden suffusion. Flowers occasionally show a white tipping. Blooms freely on good stems, making it very desirable for cutting and exhibiting.

Tubers, \$5.00; Plants, $\$ 2.50$

JEAN CHAZOT (Cayeux)-Flowers of graceful formation. Color orange suffused gold, frequently tipped golden yellow. The tall branching bushes hold the large blooms gracefully on straight stems.

JHR. G. F. VAN TETS (Kriest)-Good size white cactus with long incurving petals, fine stems hold flowers so they display their full beauty. Early and continuous bloomer. Dwarf grower.

JOSEPHINE MENDILLO (Jost)--A brilliant red which appears to be a decided improvement over Kalif, especially in substance, stem, and keeping qualities. This variety proved to be a real commercial red the past season.

Plants, $\$ 1.00$

KALIF (G. and K.)-Color, rich strawberry red, or carmine. The mammoth flowers are borne in great profusion. An old favorite and a good cut flower. Base of petals broader than illustration.

LOLITA VELASCO (Boston)-One of the most perfect white cactus dahlias. Petals are extremely long and straight. Flowers of immense size. Stem is long and stiff. Not an overly profuse bloomer and occasionally running open center.

$\$ 1.00$

MAHOGANY (Murphy)-A dark red American Cactus on a good erect stem. Large flowers of good form with full centers. Dark velvety red with a lighter reverse.

Tubers, \$2.00; Plants, $\$ 1.00$

MISS NEW YORK (Badetty)-This striking new exhibition Hybrid Cactus is one of the best. Color, deep rose, showing roselane purple on the reverse of the artistically twisted petals. A good grower, producing large, full centered blooms.

Tubers, \$2.50; Plants, \$1.25

MRS. WARNAAR (Hornsveld)-Large perfect flowers of good form and substance. Color creamy-white apple blossom suffusion. Bush compact but stems good.

.50

NIBELUNGENHORT (G. and K.)-An old favorite, often measuring from seven to eight inches in diameter; of a violet rose suffused golden apricot. Very profuse. $\mathbf{. 5 0}$

NICHU (Boston) - A hybrid cactus dahlia of real merit, described by the originator as a new Yellow King. A mass of clear yellow blooms with good stems. A strong grower and a good root maker.

Tubers, \$2.50; Plants, $\$ 1.25$

SKAGARRAK (Engelhardt)-Beautiful clear lemon vellow. Large graceful flowers of great depth with long petals. A good garden variety.

TOM LUNDY (Fenton)-A large crimson carmine of perfect form. Will give you a lot of color for your garden.

DIGGING AND STORING. After the first black frost cut off the tops at the ground and allow to stand a few days to bleed out. Then dig with a garden fork. Care should be exercised not to break the tuber necks. Cut the stalk back again to about two inches above the crown. Then by tapping on the cut stalk endwise with a light instrument most of the dirt will free without injury to the necks of the tubers. Dry in the sun a few hours and your clumps are ready to store. A root or white potato cellar is preferable with a temperature of about 40 degrees. In this they need no protection or covering. The average house cellar is too dry and hot and in such conditions the clumps should be placed in the coolest part and packed upside down in a box in dry sand, ashes, or preferably ground Peat M.oss.

After the tubers are stored a month it is well to look them over, trim out any portion showing rot and dip all the fresh cuts in equal parts of hydrated lime and sulphur, and pack them back again as before. Should the tubers show signs of shriveling place dampened Peat Moss over the top.

Dahlia tubers air dried and so packed should keep well until spring with no further handling providing they were grown properly, well ripened and not frosted. 


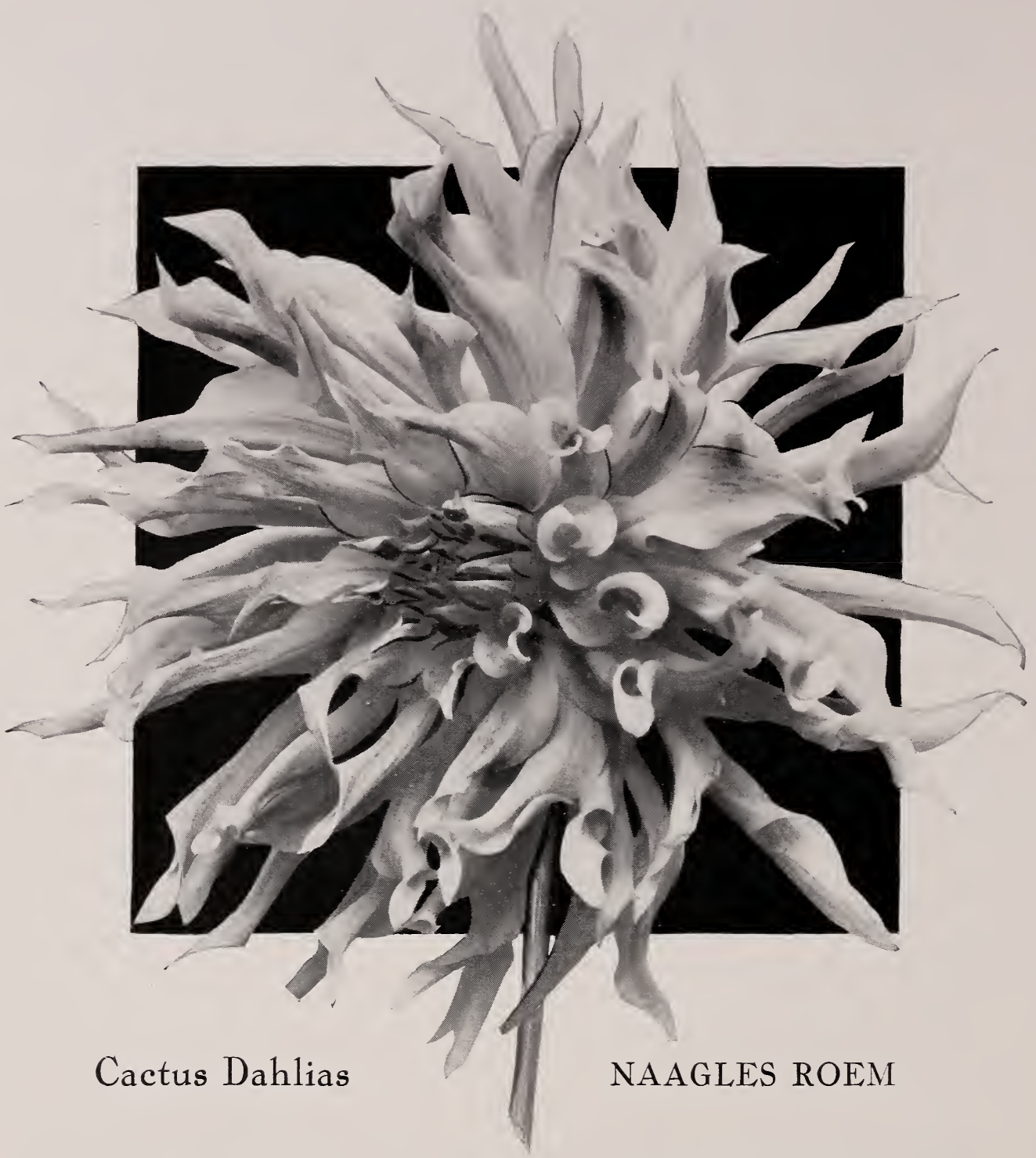

CONQUEST (West)-Rich garnet with maroon shadings. One of the best dark fine quilled cactus dahlias. Free and early.

CRYSTAL (Stredwick)-Petals long and incurved; color, soft, silvery rose, shading to white at center and tips. Stems pendant at times. Fine for florists work.

GLADYS BATES (Boston)-A huge cut flower of perfect form. Color, tan with rose reverse. A dahlia of real merit.

MME. ANNIE MARIE CHANTRE (Rivoire)-A fine large violet rose cactus dahlia; petals long straight and cleft; good for cutting.

MRS. C. G. WYATT (Keynes)-The best fine quilled pure white cactus we have found for commercial use. Early and profuse.

MRS. EDNA SPENCER (Spencer)-This popular dahlia for shipping and keeping qualities is one of the very best. Flowers produced profusely on erect stems. Color, pale lilac, shading lighter at center.

NAAGLES ROEM (Naagle)-Cactus-The most popular of Europe's recent introductions. In great demand but short stock last season. A distinctive cactus of regular formation. Excellent stems. Color buff yellow tipped rose. Tubers, $\$ 4.00$; Plants, $\$ 2.00$ 


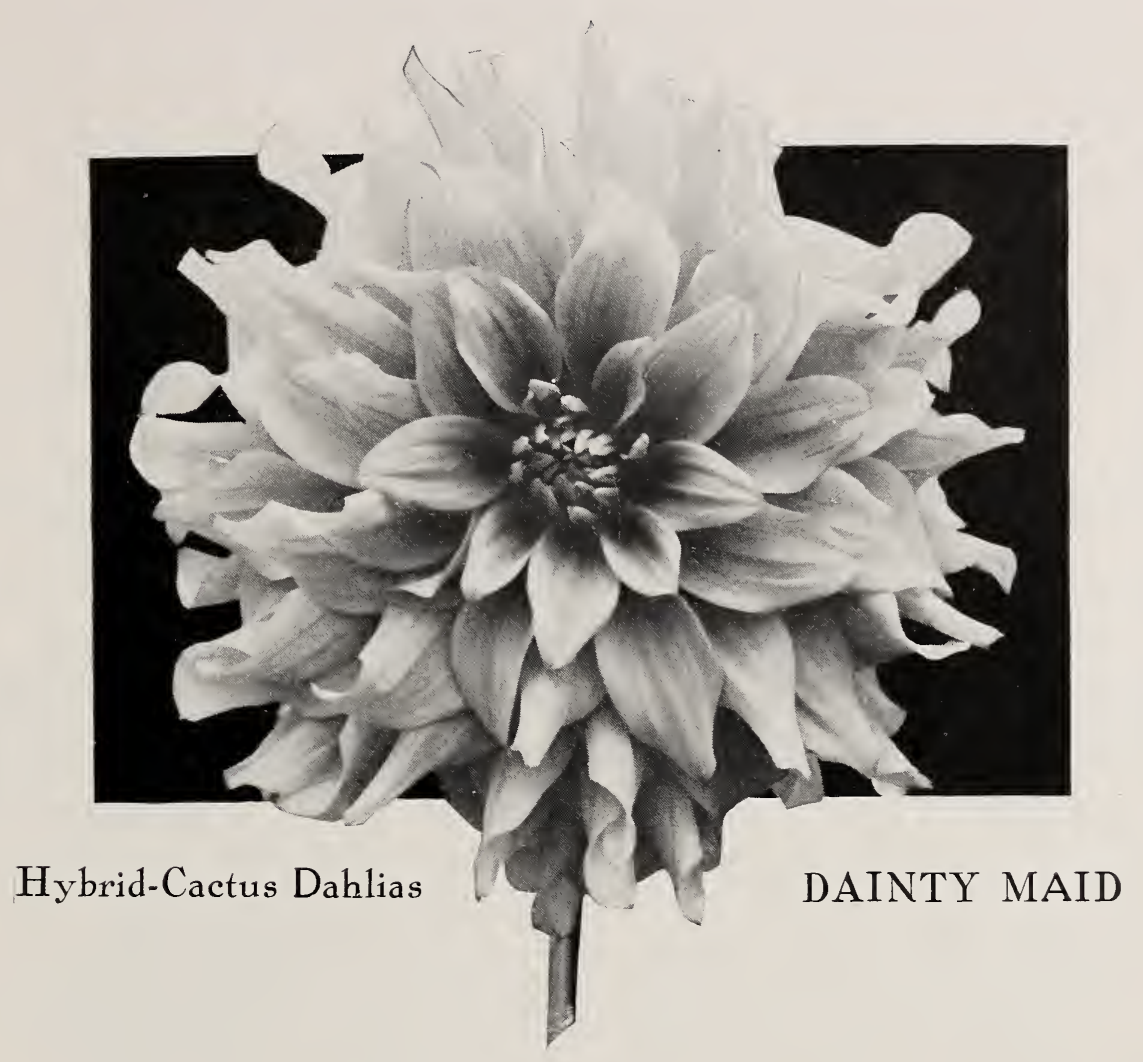

BREAK O' DAY (Dahliadel)-Now a popular standard variety. The color is a delicate, clear sulphur yellow, shading to sulphur white at tips. The petals are of great substance, illuminated by a satiny sheen, giving the flower a waxy appearance. Awarded the A. D. S. Certificate of Merit at Storrs, Conn., 1920. Also Sweepstakes at Seattle, Wash., 1921.

CIGARETTE (Boston)-Creamy white, heavily edged orange with color variations. Some flowers come all orange red. Petals are long and narrow, inclined to roll. Blooms large, on excellent stems, and of good substance. Good for cutting $\$ \mathbf{\$ 1 . 0 0}$

DAINTY MAID (Kemp)-This is the dahlia for those desiring beauty and grace and not size. It is an early and profuse bloomer on upright bushes. Color light sulphur yellow a little deeper than Break O'Day. Blooms are 4 to 6 inches on perfect stems and keep exceptionally well when cut.

Tubers, $\$ 5.00 ;$ Plants, $\$ 2.50$

SUNSET GLOW (Peacock)-Similar to Red Cross in color, but better in every way. It is a profuse bloomer, holds a full center and has good growing habits. One of the pleasing autumn shades, yellow at base of petals, suffused scarlet and tipped yellow. A good late summer cut flower.

WHITE COURT (Murphy) Hybrid Cactus-We have a good exhibition white in this dahlia. Flowers are large with long white wavy petals. Bush growth robust.

Tubers, \$5.00; Plants, $\$ 2.50$

Don't try to replace cultivating with watering. The pen may be mightier than the sword but the hoe is mightier than the hose in dahlia culture. 


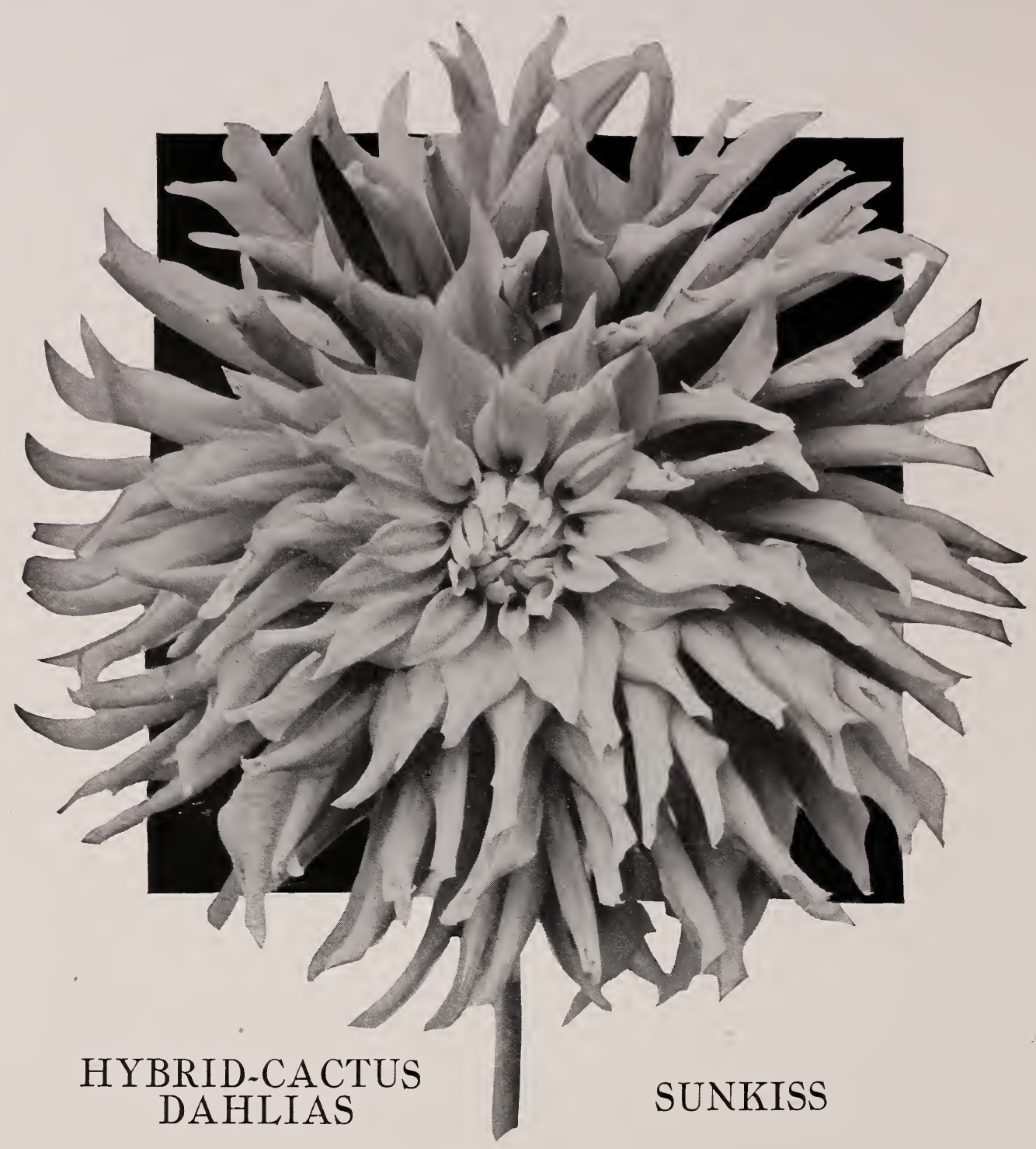

ALICE WHITTIER (Reed) Hybrid Cactus-One of the finest primrose yellow Hybrid Cactus 5 to 6 inches deep and fully 9 inches across, on long erect stems. Plants, 6 to 7 feet tall. Awarded Certificate of Merit by the A. D. S. and the D. S. of N. J.

Tubers, $\$ 5.00$; Plants, $\$ 2.50$

CHEMAR'S MASTERPIECE (Marsh)-A huge incurved cactus flower of mauve-pink or soft orchid which everyone loves. The flowers are extra large of perfect form under all conditions. A seedling of Mrs. I. de Ver Warner and a counterpart except Masterpiece is an incurved English cactus, producing ten-inch flowers in abundance. The stems are, however, partially pendant in wet weather true to the cactus type.

Tubers, $\$ 10.00$; Plants, $\$ 5.00$

DADDY BUTLER (Boston)-One of the best for exhibition. A profuse bloomer and good keeper on perfect stems. Color, rosy carmine, reverse of petals lighter. $\mathbf{\$ 1 . 0 0}$

EAGLE ROCK JEWEL (Broomall)-This is truly a beautiful color combination of cream overlaid cameo pink, while in formation it is very similar to Sunkiss illustration. Flowers are large and borne on strong stems. Bush grows about 5 feet in garden culture and is healthy and upright.

Plants, $\$ 10.00$ 


\section{HYBRID-CACTUS DAHLIAS-Continued}

EDNA FERBER (F. \& M.) Hybrid Cactus-The extreme size and beauty of this flower attracts attention wherever shown. The petals are curled and twisted, forming an extremely full flower held erect on fine stems. Color, glistening coral, shading to old gold at base of petals. Growth medium to tall with dark green foliage. Awarded D. S. of N. J. Certificate of Merit, 1925. Form similar to illustration of Sunkiss.

Tubers, \$7.50; Plants, \$3.75

ELSIE DANIELS (Meachen and Sherman)-The color of this wonderful dahlia is pale violet orchid with long, wavy white center petals. Bushes rather dwarf with immense exhibition blooms held well out of the foliage on strong stems.

Tubers, $\$ 2.00 ;$ Plants, $\$ 1.00$

J. W. LEE (Lee) Hybrid Cactus-A large strong and profuse growing dahlia of good size. Large full graceful blooms are held erect on good strong stems. Color is a blending of soft scarlet on buff yellow, giving the flower the beautiful sunset yellow at center.

$\$ 1.00$

LADY ELIZABETH. A distinct and unusual Hybrid Cactus, resembling the plume variety of chrysanthemum. Color a creamy yellow overlaid with bronzy-rose, deepening at center. The tips of quilled petals are split, giving the flower a very shaggy appearance. Free-flowering and a decided novelty.

Tubers, $\$ 1.00$

MARIPOSA (Boston)-A gigantic flower of great depth, perfect form, with incurved petals. A beautiful pink shading darker at center with a violet suffusion which adds to the effect. A sturdy grower and a great favorite.

Tubers, $\$ 1.00$

MOTHER (Peacock) -A fine white on erect stems which are well supplied with healthy green foliage. Bush sturdy. A continuous bloomer.

$\$ 1.50$

MRS. HENRY FOLEY (Murphy)-A rather unique color combination, the ground color being white shaded and suffused magenta. Flowers are large, of good form, on long erect stems. This is a free early blooming variety and decidedly different in coloring to any other variety.

Plants, $\$ 3.75$

PAULINA (Hall)-This dahlia grows to exhibition size on long strong stems. It is an early and abundant bloomer with full centered flowers. Color is a light orange suffused with amaranth pink on the reverse. Bush medium tall.

Tubers, $\$ 5.00 ;$ Plants, $\$ 2.50$

PRIDE OF MONMOUTH (Kemp) Hybrid Cactus-This fine dahlia might best be described as an improved Ambassador. Color, a rich golden buff yellow, maize reverse. Stems erect, holding flowers well out of the foliage. A prolific and early bloomer. One of the best.

Tubers, \$7.50; Plants, $\$ 3.75$

QUAKER CITY (Dahliadel)-In this fine large cactus dahlia each petal is supplemented with from three to six narrow pointed petals showing up through the flower, making a very attractive and artistic flower. Color, primrose yellow. A. D. S. Certificate, 1920.

SUN KISS (Yezek)-This fine Hybrid Cactus has such an appealing color effect of straw yellow with a heavy fawn suffusion on the outer edge that it is a universal favorite. A free and early bloomer on fine stems making it very desirable for cutting.

Tubers, \$1.50; Plants, $\$ 1.00$

ULYSSE (Vilmorin)-An appealing combination of salmon rose with golden yellow suffusion, petals broad, curling at tips. Flowers four to five inches on strong stems. Keeps wonderful when cut.

WINTER TIME (Murphy)-Fine pure white for cutting on good stems. This variety has plenty of foliage on the stems making it especially useful for sprays. $\$ \mathbf{\$ 1 . 0 0}$

\section{DAHLIA TUBERS THAT WILL WINTER}

First, side-step the varieties that are habitual poor root makers, such as Geisha and Pres. Wilson, etc.

Second, plant only stock that has been properly grown without previous forcing.

Third, fertilize so that your plants will have a balanced ration, namely nitrogen in manures, humus, or bone meal; and phosphoric acid in acid phosphate or bone meal, and potash in wood ashes, sulphate, or muriate of potash.

Fourth, cultivation is worth more than watering for healthy plant growth. Water thoroughly only when necessary (not more than once a week in a dry spell), but culti. vate once a week throughout the season, until the middle of September, then stop. This check will help materially in ripening the tubers.

Selected stock in either green plants or tubers properly fertilized, watered, and cultivated will produce wonderful blooms and the tubers will have every chance of wintering. A complete starch formation is essential for the proper wintering of a dahlia tuber and the above suggestions are essential. 


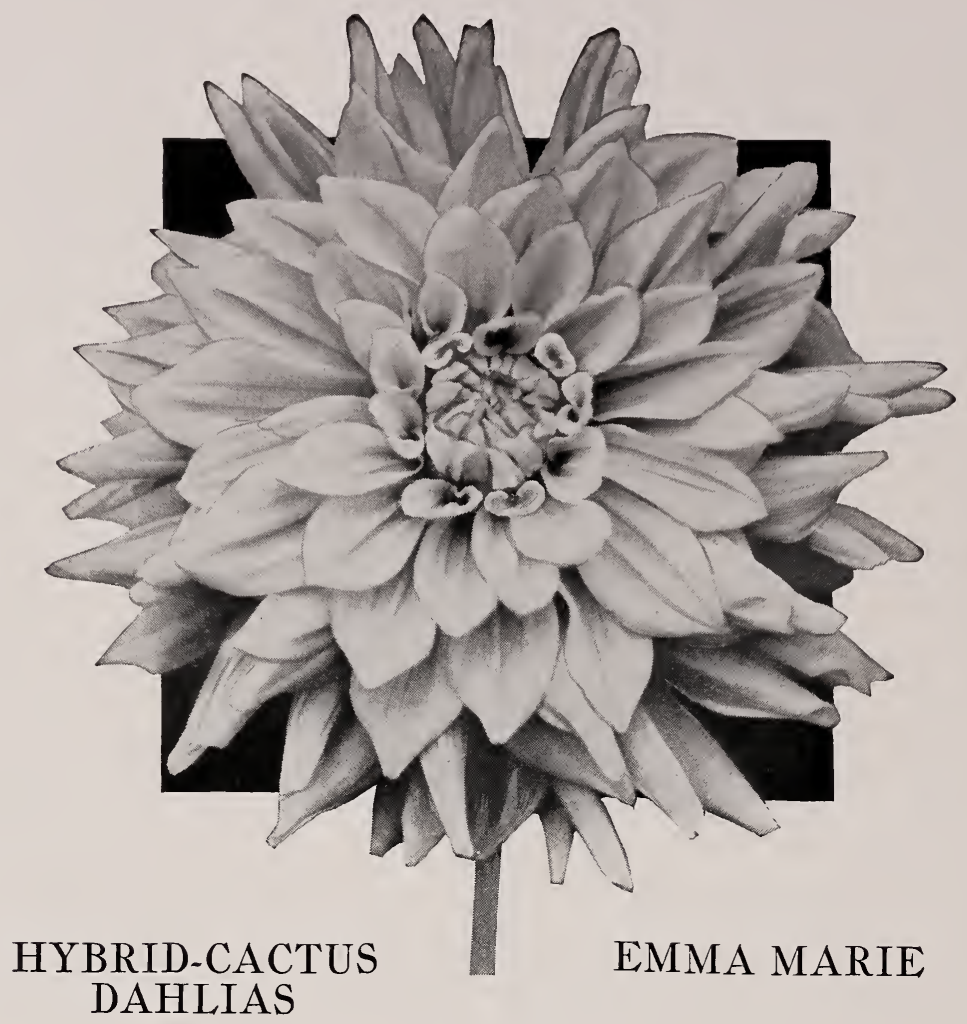

AUBURN BEAUTY (Weston)-A pleasure to grow as the bushes are strong and healthy, producing blooms from 8 to 9 inches across and 4 to 5 inches deep, on rather slender, wiry stems. Color, bright gold shaded and suffused coppery red.

Tubers, $\$ 2.50$; Plants, $\$ 1.25$

EMMA MARIE (Dahliadel)-The Charming Pink Dahliadel Introduction without a rival. Its beautiful coloring, perfect form and exceptional keeping qualities win friends everywhere.

A favorite because of its pleasing shade of clear pink with a creamy white center and its combination of exhibition and commercial qualities not found in many Dahlias. It is a robust grower, producing deep, full-centered blooms from 6 to 8 inches in diameter on three to four foot stems in ordinary field culture.

Tubers, $\$ 2.00 ;$ Plants, $\$ 1.00$

GEORGE WALTERS (Carter)-An old friend, still attractive and popular. A free and early bloomer with an occasional open center. Color, coppery old gold with buff rose reverse.

.50

GRISETTE (Boston)-A hybrid cactus of exhibition size and good formation. Large flowers are of great depth composed of numerous closely rolled petals. Color old gold heavily flushed pink.

Tubers, $\$ 1.50$

HARRY SHELDON, JR. (Murphy)-Although a massive decorative for exhibition it is a beauty with wavy petals and of delicate coloring, passing from white at center to shell pink on outer petals.

Tubers, \$2.50; Plants, $\$ 1.25$

JERSEY'S SWEETHEART (Waite) Decorative-A dainty attractive variety for cutting. Delice pink shading to white in the center. Flowers produced in great quantities with a slender, stiff stem. Cert. 1926.

Tubers, \$2.50; Plants, $\$ 1.25$

SOLE MIO (Pelicano)-This fine large dahlia is very desirable for garden or exhibition. Color deep yellow suffused apricot. Flowers are of good substance and held high on excellent stems. A dahlia you will be well pleased with.

Plants, \$2.00

WASHINGTON CITY (Broomall)-A fine large pure white, looking almost like a white star. Fine bush growth. 


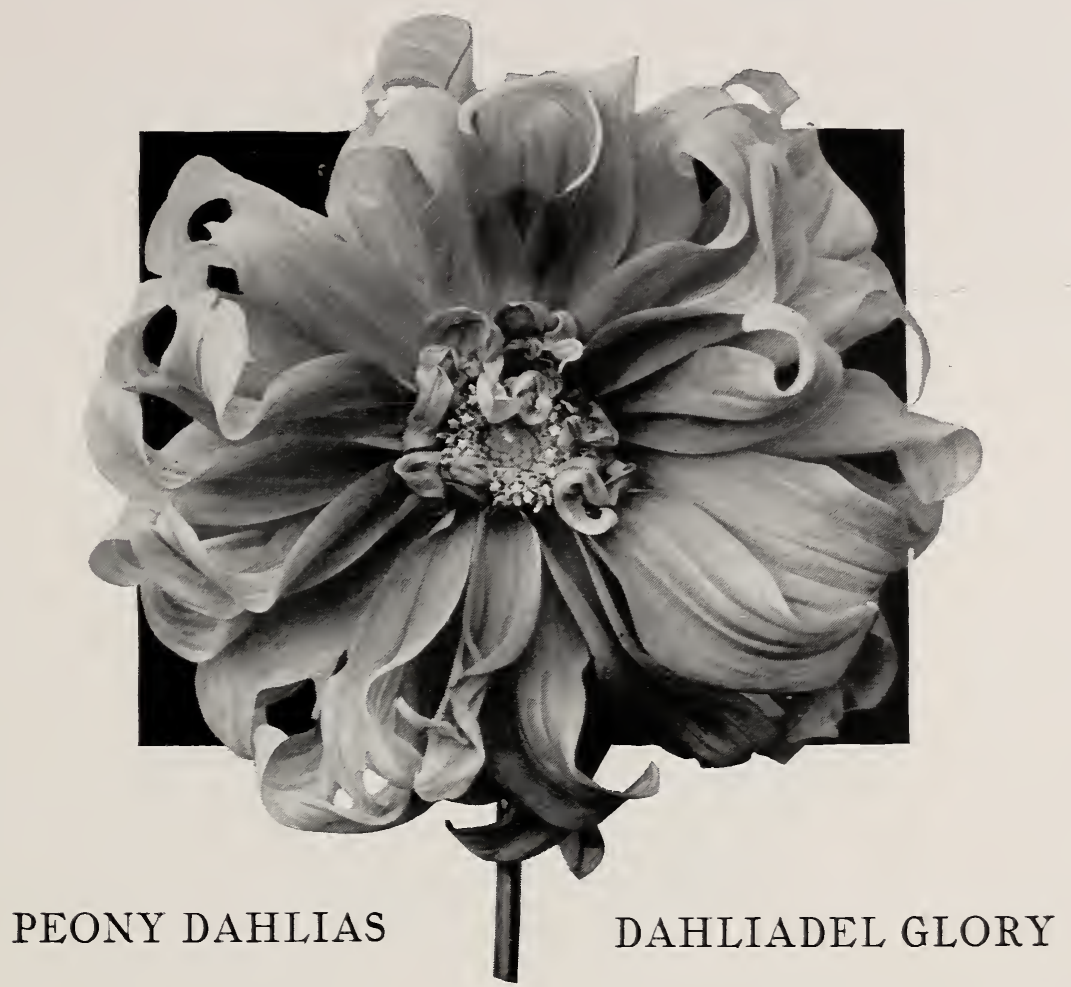

CANADA (Peacock)-One of the best and hardiest pure white peonies. Bush dwarf but produces an abundance of blooms on erect stems well above the foliage.

CITY OF PORTLAND (Chamberlain)-The best and largest clear yellow peony dahlia we have found producing exhibition blooms from early to late on erect stems.

$\$ 1.00$

DAHLIADEL GLORY (Dahliadel, 1925)-We, like many others, are prejudiced against peony dahlias because so many floppy duplex varieties have been introduced, but this new dahlia has a very artistic formation of broad, heavy petals, with a beautiful whirl center, on long, erect stems. A wonderful color blending of scarlet tipped reddish apricot, giving a henna effect.

$\$ 1.00$

DRUM MAJOR (Dreer)-One of the largest of the peony flowered type. A rich fiery red with a lemon yellow center and petals more or less tipped and marked yellow. A prominent variety in the garden.

$\$ 1.00$

GEISHA (Hornsveld)-Buttercup yellow at base of petals shading to scarlet at center, and passing lighter at tips. Petals broad, loose and peculiarly twisted.

KING ALBERT (DuBois)-Large and graceful flowers of rich royal purple on good Stems. Bush tall.

MRS. FRANCES E. BULLARD (Broomall)-This is the largest peony in our list. The petals are long, pointed and gracefully twisted forming a very distinct flower of a clear silver or pastel pink shading slightly lighter at the center, and do not be at all disappointed if it comes with a full center which it does at times. Bush about 4 feet, free early and profuse, on strong stems.

Tubers, $\$ 3.00$; Plants, $\$ 1.50$

MRS. THOS. BUSH-Color, reddish salmon, shading primrose yellow at center and tipped rose. Good size on pendant stems but an incessant bloomer.

QUEEN ELIZABETH (Peacock)-A fine formed peony of clear violet rose. Stems erect. Bush medium height. 


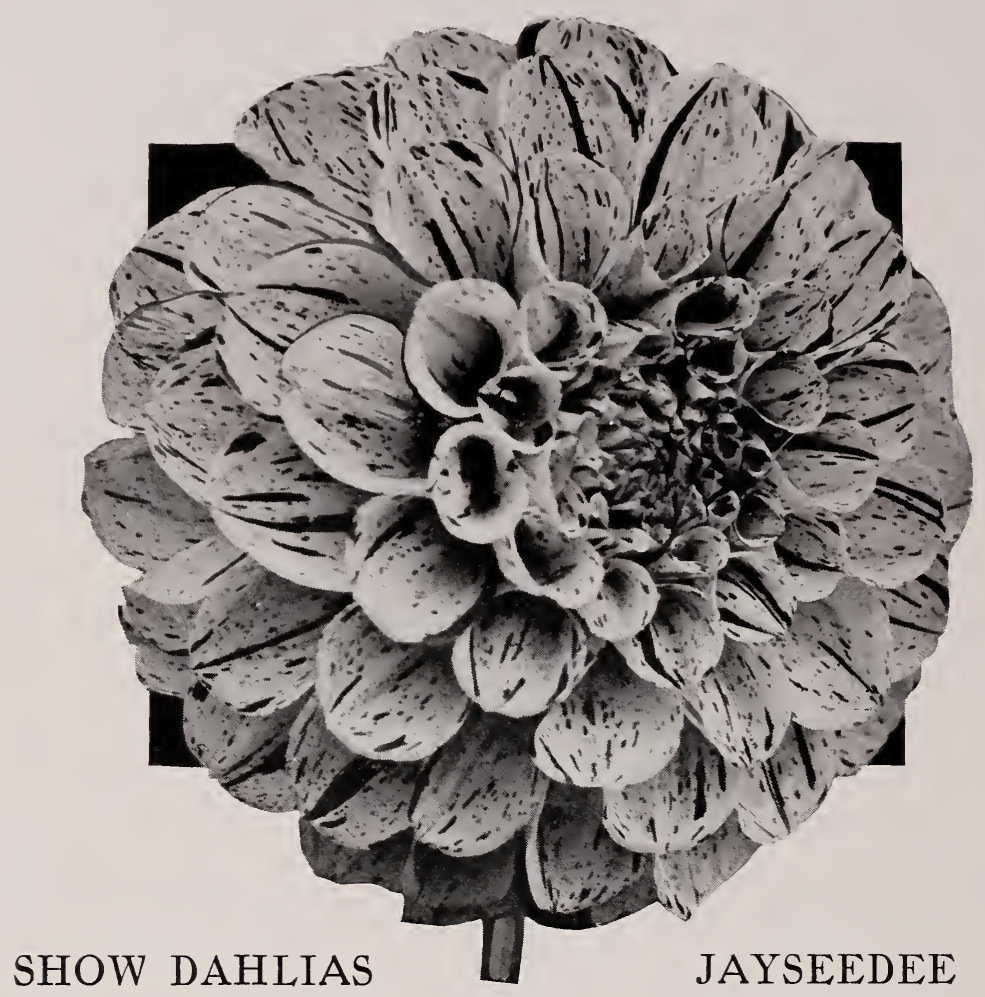

CARL OWEN (Dahliadel)--The best red show we have found. Rich non-fading carmine red. Flowers of perfect form on erect stems. Good without disbudding.

DOROTHY PEACOCK (Peacock)-A beautiful pale lilac rose shading to a white at center; of fine branching habit.

DRAUDE (Draude)-The finest dark red ball dahlia of perfect form. Bush rather dwarf with nodes very close; requires disbudding to produce stems but a wonderful stem when you do.

DREER'S WHITE (Dreer)-Snow white flowers of good form borne in great profusion. Stems pendant.

DREER'S YELLOW (Dreer)-A beautiful rich deep sulphur yellow of perfect form, blooms well above the foliage. Often measuring seven inches in diameter. Similar to Dreer's White in form and a very healthy grower.

FLORENCE (Dahliadel-Pfeiffer)-This variety is always a mass of blooms. Perfect form and good size. Color a very pleasing shade of pale light lilac.

GOLDEN WEST HS (Burbank)-Large and distinct; high full center with petals notched at tips. Color, clear primrose yellow.

GOLD MEDAL (Keynes)-Sunflower yellow tipped and suffused Oriental red; very striking and becoming more popular each year.

JAYSEEDEE (Draude)-A beautiful new ball shaped dahlia of soft reddish violet striped and speckled rich deep red. A perfect ball. Bush compact but fine stems can be produced by disbudding. 


\section{POMPON DAHLIAS}

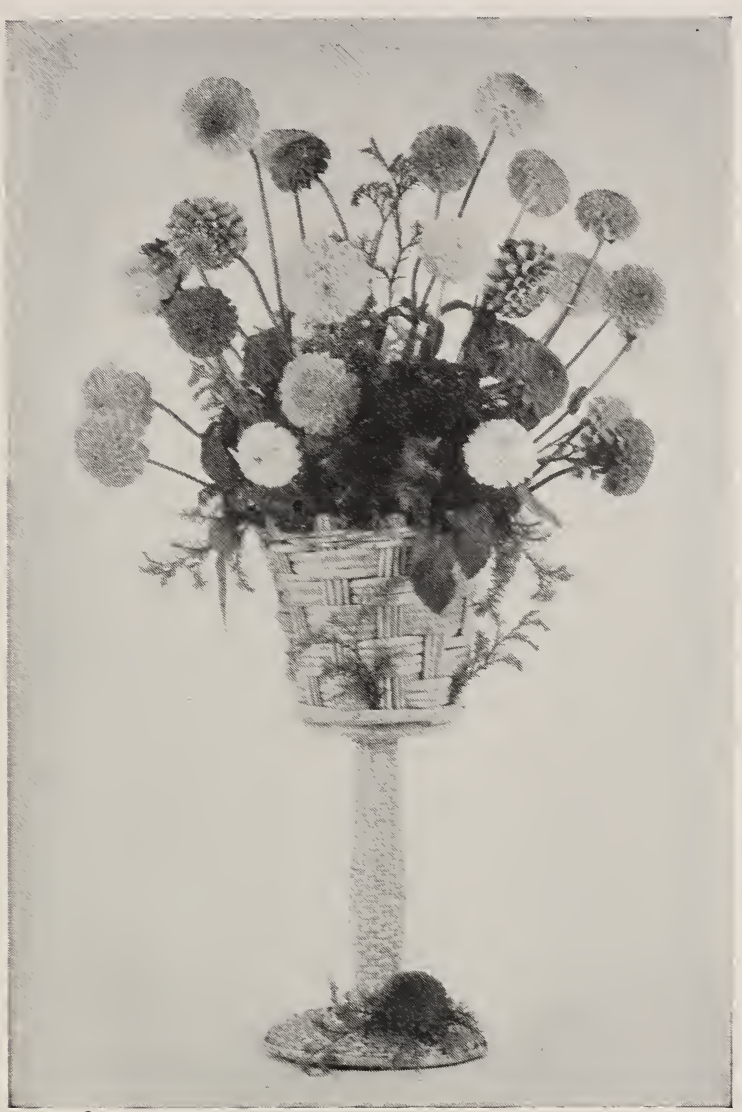

BELLE OF SPRINGFIELDSoft red. One of the smallest and popular on the exhibition table.

.50

BOBBY-Bright p $1 \mathrm{um}$ color. Bush rather tall.

BRONZE BEAUTY-Beautiful golden apricot; a free bloomer good for cutting.

25

CATHERINE-Clear canary yellow.

25

DARKSOME (Alexander) The best real dark red or maroon.

DEE DEE (Estes) - Very small. Pale lilac, fine for exhibition.

.50

DEW DROP-White tipped lavender.

.50

ELEGANTA-D e e p p in $k$, quilled petals.

.35

ELFIN-Very small and dainty. Light primrose yellow.

FASCINATION-V e $r$ y fine pink and lavender with white undershadings.

.25

KLEINE DOMITEA - Bright orange buff, low grower.

LITTLE BELLE-Very fine mauve pink .50

LITTLE HELEN-Fine bloomer, lirely pale larender.

LITTLE HERMAN-Cardinal red shaded maroon tipped white.

LOLITA (Salbach)-Beautiful rich yellow with a prominent brownish red center. $\$ 1.00$

MIDGET (West)-Salmon suffused with riolet.

NEATNESS (IVest) - Light amber center shading to salmon pink.

PHYLLIS (Turner)-Deep yellow shaded and edged red. Very fine.

ROSEA (Keynes)-Perfect form for exhibition. Rosy lavender.

SAN TOY (Turner)-One of the favorites. White tinged carmine rose. 


\section{Dahlia Growers Supplies}

DAHLIADEL PLANT FOOD-Made especially for Dahlias, of the highest grade materials, for the production of fine flowers and strong tubers, and so blended to have a balanced food available as needed by the plant. Good also for all out door flowers and vegetables. A very economical fertilizer.

Directions: Spring application, 3 to $6 \mathrm{lbs}$. to each $100 \mathrm{sq}$. ft. August application, 3 to $4 \mathrm{lbs}$. This may be divided into 3 applications but not over $10 \mathrm{lbs}$. to 10 hills should be applied during a season.

Price F. O. B. Factory in Baltimore, 50 lbs., $\$ 3.00 ; 100$ lbs., $\$ 5.50 ; 200$ lbs., $\$ 10.00$; Ton, $\$ 90.00$.

DAHLIADEL NICOTONE-A $3 \%$ nicotine dust. $5 \mathrm{lbs}, \$ 1.50: 25 \mathrm{lbs}$., $\$ 5.75$ by Express Collect. By Parcel Post prepaid, including the 4th zone, 1 lb., .50; 2 lbs., .90; 5 lbs., $\$ 1.75$. For distant shipments include additional postage.

DAHLIADEL DUSTING OUTFIT-Consisting of one Feeny pump type duster with extension spout for dusting small plants without stooping, and $1 \mathrm{lb}$. Dahliadel Nicotine. Postpaid including the 4 th zone, $\$ 2.10$, with $2 \mathrm{lbs}$. of nicotine, $\$ 2.50$. For distant shipments include additional postage.

VERMOREL “ORANGE" DUSTER-The best knapsack duster we have found for applying nicotine dust. Price $\$ 15.00 \mathrm{~F}$. O. B. Vineland. Shipping weight, $18 \mathrm{lbs}$.

PRUNING SHEARS-Made especially for root cutting. The double cutting blades are curved and pointed making them the best type for dividing dahlia clumps. This is the shear we are using for all our dividing and trimming. Suitable for general pruning as well. Postpaid $\$ 4.00$.

MODERN DAHLIA CULTURE-By W. H. Waite. Written to meet the needs of the novice and to interest the expert. 126 pages of clear type, well illustrated. Cloth binding. The best book to date. $\$ 1.60$ postpaid.

\section{DAHLIADEL COLLECTIONS}

It is with pride we offer such wonderful values and up to date varieties. We have over one-half million dahlia tubers this year and we want you to enjoy growing "POTASH FED DAHLIAS".

\section{A-INTRODUCTORY COL.}

$\$ 1.00$

Value $\$ 2.35$

Dorothy Robbins

Geo. Walters

Lotus

Mrs. Carl Salbach

Pride of California

\section{BEGINNERS SURPRISE COLLECTION}

\section{$\$ 2.00$}

Value, $\$ 6.00$ to $\$ 8.00$

12 fine named varieties tagged. This collection is made up of different varieties than those used last season. It is a wonderful assortment of types and colors. No Singles or Poms. The greatest value ever offered.

\section{BEAUTY COLLECTION}

$\$ 3.00$

Value $\$ 5.00$

Earle Williams

Elberon Beauty

Frances Lobdell

Jersey's Beauty

Mariposa

\section{D-DECORATIVE COL.}

$\$ 6.00$

Value $\$ 9.50$

City of Lawrence

Jersey's Sovereign

Pride of Dahliadel

Sagamore

Sanhican's Bluebird

\section{C-CACTUS COL.}

$\$ 4.00$

Value $\$ 6.00$

Ambassador

C. B. Githens

Cigarette

Daddy Butler

Mahogany

\section{STAR COLLECTION}

$\$ 7.50$

Value $\$ 12.00$

Chas. Stratton

Eastern Star

Jersey's Beacon

Margaret Masson

World's Best White
MARIE COLLECTION

$\$ 5.00$

Value $\$ 7.50$
Champagne

E. B. Roberts

Emma Marie

Sunny Jersey

Trentonian

\section{WARE COLLECTION}

$\$ 10.00$

Value $\$ \mathbf{1 5 . 0 0}$

Casper G. Ware

Margaret W. Wilson

Mordella

Nichu

Roman Eagle 


\section{GLADIOLUS}

The varieties we are listing have been selected to meet the requirements of the most exacting cut flower market and should give the greatest satisfaction when grown in your garden. They are strong bloomers with straight spikes, flowers set close and of the pleasing, bright shades. A very popular and easily grown summer flower.

Bulbs listed below will average considerably orer $1 \frac{1}{2} 2$ inches in diameter. Shipped prepaid, except hundred rates West of the Mississippi. 6 at dozen rates, 25 at 100 rates.

ALBANIA (Kemp)-An ideal cut flower. Color, pure glistening white. Five flowers open at one time, $t$ inches across.

3 for $.45 ; 12$ for $\$ 1.50$

ALICE TIPLADY (Prim)-Beautiful soft coppery bronze. Flowers large and of splendid form and very early bloomer.

3 for $.30 ; 12$ for $\$ 1.00 ; 100$ for $\$ 7.00$

CRIMSON GLOW-A glowing, velvety crimson scarlet shading deeper in the center. Large open flowers on strong spikes. A good grower. 3 for $.35 ; 12$ for $\$ 1.25$

DR. VAN FLEET-Early rose pink with yellow throat, spikes long.

3 for $.45 ; 12$ for $\$ 1.50$

E. J. SHAYLOR-Beautiful deep rose pink. A large cut flower of the ruffled type. 3 for $.35 ; 12$ for $\$ 1.25 ; 100$ for $\$ 8.00$

EVELYN KIRTLAND-Flowers large, slightly fluted and many open at one time. Color, rose pink, passing to shell pink with fiery red blotches.

3 for $.25 ; 12$ for $.85 ; 100$ for $\$ 6.00$

GOLDEN MEASURE-This handsome, rich yellow produces strong spikes well filled with large flowers. One of the best yellows grown. 3 for .45; 12 for $\$ 1.50$

HERADA-A splendid variety of pure maure with deeper markings. Fine for florists' use.

3 for $.30 ; 12$ for $\$ 1.00$

LILY WHITE-Large open lily-like flowers of pure white. A fine early grower on long spikes. One of the best.

3 for $.25 ; 12$ for $.85 ; 100$ for $\$ 6.00$

LOUISE-Wide open flowers on strong spikes. Orchid lavender with deeper blotch in throat.

3 for .45 ; 12 for $\$ 1.50$

LOVELINESS-Dainty flowers of salmon pink with a touch of yellow in the throat. Tall strong grower producing wonderful spikes.

3 for $.45 ; 12$ for $\$ 1.50$

MAIDEN'S BLUSH (Prim)-Delicate shell pink flowers of good form. A prolific grower and bloomer. The best pink of this type. 3 for $25 ; 12$ for $.85 ; 100$ for $\$ 6.00$

MARY PICKFORD-One of the dainty newer varieties. A creamy white with a soft canary throat. Flowers large and well expanded.

3 for $.35 ; 12$ for $\$ 1.25$

MRS. DR. NORTON-Silvery white shaded soft pink, deepening toward the edge of petals, with creamy blotches in throat. A tall grower, good for cutting.

3 for $.30 ; 12$ for $\$ 1.00 ; 100$ for $\$ 7.50$

MRS. H. E. BOTHIN-Geranium pink tinted salmon, scarlet center. A beautiful ruffled variety on strong stems.

3 for $.45 ; 12$ for $\$ 1.50$

1910 ROSE-Beautiful bright pure rose pink with narrow white stripes on lower petals.

3 for $.30 ; 12$ for $\$ 1.00$

ROSE PRECOSE-Salmon rose slightly ruffled, many open at one time on long, straight spike.

.25 each; 12 for $\$ 2.50$

SOUVENIR (Prim)-One of the purest golden yellows. Large beautifully shaped flowers on tall spikes.

3 for $.35 ; 12$ for $\$ 1.25$

\section{DAHLIADEL GLAD MIXTURE}

This mixture is made up of all good standard named varieties and comprises a well balanced assortment. Sure to please.

12 for $.75 ; 100$ for $\$ 5.00$ 
I N D E X

\begin{tabular}{|c|c|c|c|c|c|c|c|}
\hline \multicolumn{2}{|c|}{ Page } & \multirow{2}{*}{$\frac{\text { Tubers }}{\$ 5.00}$} & \multirow{2}{*}{$\frac{\text { Plants }}{\$ 2.50}$} & \multicolumn{2}{|c|}{ Page } & \multirow{2}{*}{$\frac{\text { Tubers }}{.50}$} & \multirow{2}{*}{$\underline{\text { Plants }}$} \\
\hline 26 & Adda Patterson- $\mathrm{HC}$ & & & 14 & Freckles_D & & \\
\hline 30 & Alice Whittier-HC & 5.00 & 2.50 & $\begin{array}{r}2 \\
24\end{array}$ & F. T, D. $-\mathrm{D} \ldots$ & 7.50 & 3.75 \\
\hline 18 & Altamont $-\mathrm{L}$ & 5.00 & 2.50 & 24 & $\begin{array}{l}\text { F. W. Fellows-C } \\
\text { Galli-Curci-HC }\end{array}$ & .75 & \\
\hline 16 & Amarillo Grande-H D & & 2.50 & 33 & $\begin{array}{l}\text { Gall1-Curc1-HC, Net } \\
\text { Geisha-P } \ldots \ldots \ldots \ldots\end{array}$ & $\cdots \cdot \dot{5}$ & 7.50 \\
\hline $\begin{array}{r}25 \\
+\end{array}$ & Ambassador $-\mathrm{C} \quad \cdots$ & $\begin{array}{r}1.00 \\
.75\end{array}$ & $\cdots$ & 32 & Geo. Walters- $\mathrm{H} \mathrm{C}$ & $\begin{array}{l}.75 \\
.50\end{array}$ & $\cdots$ \\
\hline $\begin{array}{r}4 \\
32\end{array}$ & $\begin{array}{l}\text { Amun } \mathrm{Ra}-\mathrm{D} \\
\text { Auburn Beauty-H } \mathrm{H}\end{array}$ & 2.50 & $\ddot{1} . \dot{2} \dot{5}$ & 9 & Giant Ruby-D ... & 1.00 & \\
\hline 22 & Augustinus $-\pi \nu \ldots$ & .75 & $\ldots$ & 28 & Gladys Bates-C . . & .75 & -. \\
\hline 23 & Autumn Cen.-Sing. & .25 & $\dddot{100}$ & $\begin{array}{r}14 \\
6\end{array}$ & $\begin{array}{l}\text { Glory of Argonne-D } \\
\text { Glory of Monmouth }-\end{array}$ & $\begin{array}{r}.50 \\
5.00\end{array}$ & $\ddot{2} . \dot{5} 0$ \\
\hline $\begin{array}{l}4 \\
4\end{array}$ & $\begin{array}{l}\text { Autumn } \text { Queen-D } \\
\text { Azalea-D } D . . . \ldots\end{array}$ & $\begin{array}{r}2.00 \\
.50\end{array}$ & 1.00 & 22 & Golden Fleece-D. & 7.50 & 3.75 \\
\hline 18 & Aztec Glory-HD & & $\ddot{5} .00$ & 22 & Golden Jubilee-D & 4.00 & 2.00 \\
\hline 24 & Ballet Girl-C .... & .75 & $\cdots$ & $\begin{array}{l}3+ \\
34\end{array}$ & $\begin{array}{l}\text { Golden West-HS } \\
\text { Gold Medal-S .. }\end{array}$ & $\begin{array}{l}.35 \\
.50\end{array}$ & \\
\hline $\begin{array}{l}12 \\
14\end{array}$ & $\begin{array}{l}\text { Bashful Giant-D } \\
\text { Beatrice Slocombe-D }\end{array}$ & $\begin{array}{l}.75 \\
.75\end{array}$ & $\cdots$ & 16 & Grandola-D & .50 & $\ddot{2.50}$ \\
\hline $\begin{array}{r}1+ \\
8\end{array}$ & $\begin{array}{l}\text { Beatrice Slocombe-D } \\
\text { Betty-D .......... }\end{array}$ & 1.00 & $\cdots$ & 32 & Grisette-HC & 1.50 & \\
\hline 29 & Break O'Day-HC & .50 & $\cdots$ & $\begin{array}{l}8 \\
5\end{array}$ & $\begin{array}{l}\text { Halvella-D }-\mathrm{D} \\
\text { Harry Mayer-D }\end{array}$ & $\begin{array}{r}1.00 \\
10.00\end{array}$ & $5.0 \mathrm{C} \longrightarrow$ \\
\hline $\begin{array}{r}4 \\
26\end{array}$ & $\begin{array}{l}\text { Breeze Lawn-D } \\
\text { California Beauty- }\end{array}$ & $\begin{array}{l}.50 \\
.50\end{array}$ & $\cdots$ & 32 & Harry Sheldon, Jr.- $\mathrm{HD}$... & 2.50 & $\begin{array}{l}5.00 \\
1.25\end{array}$ \\
\hline 33 & Canada $-\mathrm{P} \quad \ldots . . .$. . & .35 & $\cdots$ & 15 & Harvest Moon-D & .50 & \\
\hline 34 & Carl Owen-S & .05 & $\cdots$ & $\begin{array}{l}17 \\
20\end{array}$ & $\begin{array}{l}\text { Hathor-D } \ldots . . . \\
\text { His Majesty-HD }\end{array}$ & 5.00 & 2.5 \\
\hline $\begin{array}{l}8 \\
4\end{array}$ & $\begin{array}{l}\text { Carmencita-D } \\
\text { Casper G. Ware }-D\end{array}$ & 1.00 & $\ddot{1} \ddot{5} \dot{0}$ & 27 & Ian-C & $\begin{array}{l}2.00 \\
5.00\end{array}$ & 2.5 \\
\hline $\begin{array}{r}4 \\
26\end{array}$ & $\begin{array}{l}\text { Casper G. Ware-D } \\
\text { C. B. Githens-HC }\end{array}$ & $\begin{array}{l}3.00 \\
1.00\end{array}$ & $\begin{array}{l}1.50 \\
\ldots . .\end{array}$ & 20 & Insulinde-H $-\mathrm{H}$ & .75 & 2.0 \\
\hline & Champagne-D $\ldots$. & 1.50 & $\cdots \cdots$ & $\begin{array}{l}17 \\
13\end{array}$ & $\begin{array}{l}\text { Islam Patrol-D } \ddot{D} \\
\text { Jack O'Lantern-D }\end{array}$ & 2.00 & 1.0 \\
\hline $\begin{array}{l}14 \\
18\end{array}$ & & .75 & $\dddot{0} \ddot{0} 0$ & 2 & Jane Cowl-HD & $\begin{array}{r}7.50 \\
15.00\end{array}$ & $\begin{array}{l}3.75 \\
7.50\end{array}$ \\
\hline $\begin{array}{l}18 \\
30\end{array}$ & $\begin{array}{l}\text { Chas. Stratton-HD } \\
\text { Chemar's Masterpiece }\end{array}$ & 2.00 & $\begin{array}{l}1.00 \\
5.00\end{array}$ & 6 & Hall-D $D$ & 1.00 & 1.00 \\
\hline 29 & & $\begin{array}{r}10.00 \\
1.00\end{array}$ & 5.00 & 34 & Jayseedee-S $\ldots .$. & 1.00 & \\
\hline 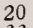 & City of Lawrence- & 2.50 & 1.25 & 27 & Jean Chazot-HC & .75 & \\
\hline 33 & City of Portland-P & 1.00 & & 15 & & $\begin{array}{r}10.00 \\
.50\end{array}$ & 5.0 \\
\hline $\begin{array}{r}2 \\
16\end{array}$ & City of Trenton-D & 10.00 & 5.00 & 13 & Jersey's Beacon- $\mathrm{D}$ & 2.50 & 1.2 \\
\hline $\begin{array}{l}16 \\
20\end{array}$ & Color Sergeant-D . & 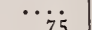 & 3.75 & 10 & Jersey's Beauty-D & 1.00 & \\
\hline $\begin{array}{l}20 \\
28\end{array}$ & $\begin{array}{l}\text { Comstock-HD } \ldots . \\
\text { Conquest-C } \ldots . . . .\end{array}$ & $\begin{array}{l}.75 \\
.50\end{array}$ & $\ldots$ & 2 & Jersey's Daybreak-D & & 5.0 \\
\hline $\begin{array}{l}28 \\
28\end{array}$ & Crystal- $-\mathrm{C} \ldots \ldots$. & $\begin{array}{l}.50 \\
.35\end{array}$ & $\cdots$ & 19 & Jersey's Empress-D & 5.00 & 2. \\
\hline 30 & Daddy Butler-HC & 1.00 & $\cdots \cdots$ & $\begin{array}{l}17 \\
10\end{array}$ & Jersey's Fiancee-D & 5.00 & 2.5 \\
\hline $\begin{array}{l}23 \\
33\end{array}$ & Dahliadel Century- & .25 & .... & 19 & $\begin{array}{l}\text { Jersey's Gem-D } \ldots \\
\text { Jersey's Ideal-D } \ldots\end{array}$ & 1.00 & .5 \\
\hline 33 & Dahliadel Glory $-\mathrm{P}$ & 1.00 & & 17 & $\begin{array}{l}\text { Jersey's Ideal-D } \\
\text { Jersey's Monarch-D }\end{array}$ & $\begin{array}{l}5.00 \\
2.50\end{array}$ & $\begin{array}{l}2.5 \\
1.2\end{array}$ \\
\hline 29 & Dainty Maid- $\mathrm{HC}$ & 5.00 & 2.50 & 19 & Jersey's Sovereign-D & 2.00 & $\begin{array}{l}1.25 \\
1.00\end{array}$ \\
\hline $\begin{array}{l}6 \\
9\end{array}$ & Dakota-D $\ldots \ldots$. & .75 & … & 32 & Jersey's Sw & 2.50 & 1.25 \\
\hline $\begin{array}{r}9 \\
14\end{array}$ & Delice-D …...... & .35 & $\cdots$ & 27 & Jhr. G. F. Van Tets-HC . & .75 & \\
\hline 34 & $\begin{array}{l}\text { D. M. Moore-D }-\dot{S} \\
\text { Dorothy Peacock-S }\end{array}$ & .50 & $\cdots$ & 19 & Jim George-D & 3.50 & 1.7 \\
\hline 16 & $\begin{array}{l}\text { Dorothy Peacock-S } \\
\text { Dorothy Robbins-D }\end{array}$ & $\begin{array}{l}.35 \\
.50\end{array}$ & $\cdots \cdots$ & 10 & John Lewis Childs-D $\ldots$. & 1.00 & \\
\hline 34 & Draude $-\mathrm{S} \ldots \ldots$. & .75 & $\cdots$ & 22 & $\begin{array}{l}\text { Josephine Mendillo-HC } \ldots \\
\text { J. Otto Thilow-D } \ldots . . . \ldots\end{array}$ & .50 & 1.00 \\
\hline $\begin{array}{l}34 \\
34\end{array}$ & Dreer's White- $S$. & .25 & $\cdots$ & & Judge Shinn-HD & & 5.06 \\
\hline $\begin{array}{r}34 \\
8\end{array}$ & Dreer's Yellow-S & .50 & $\cdots \cdot$ & 31 & J. W. Lee-HC. & 1.00 & \\
\hline $\begin{array}{r}8 \\
33\end{array}$ & $\begin{array}{l}\text { Dr. Tevis-D } \\
\text { Drum Major-P }\end{array}$ & .50 & $\cdots$ & 27 & Kalif-HC ....... & .50 & \\
\hline $\begin{array}{l}33 \\
20\end{array}$ & $\begin{array}{l}\text { Drum Major-P } \\
\text { Eagle Rock Beauty- }\end{array}$ & $\begin{array}{r}1.00 \\
10.00\end{array}$ & $\ddot{5} \ddot{0} \dot{0}$ & & Kemp's Lavender--D & 7.50 & 3.7 \\
\hline $\begin{array}{l}20 \\
30\end{array}$ & $\begin{array}{l}\text { Eagle Rock Beauty- } \\
\text { Eagle Rock Jewel-H }\end{array}$ & 10.00 & 10.00 & & $t$ Wonde & 15.00 & 7.5 \\
\hline 25 & $\begin{array}{l}\text { Eagle Rock Jewel-HC } \ldots \ldots \\
\text { Eagle Rock Sunshine-C } \ldots\end{array}$ & 7.50 & 3.75 & $\begin{array}{r}33 \\
5\end{array}$ & Alb & .50 & $\cdots$ \\
\hline & $\begin{array}{l}\text { Eagle Rock Sunshine-C } \\
\text { Earle Williams-D } \ldots \ldots \ldots\end{array}$ & 1.00 & & 15 & $\begin{array}{l}\text { Kitty Dun } \\
\text { Laddie-D }\end{array}$ & $\begin{array}{r}1.00 \\
.75\end{array}$ & \\
\hline 19 & E. B. Roberts-D & 1.50 & & 31 & Lady Elizabeth- & 1.00 & \\
\hline 12 & Eastern Star-D . & 3.00 & 1.50 & 17 & Lady Lyn & & 3.7 \\
\hline 23 & Eckford Century-Ce & .25 & & & La Grosse Bete-D & .7 & \\
\hline 26 & Eclipse Beauty $-\mathrm{C}$ & 5.00 & 2.50 & 21 & $e-\mathrm{HD}$ & .75 & \\
\hline 31 & Edna Ferber-HC & 7.50 & 3.75 & 21 & La Roda-D & & 10.00 \\
\hline 20 & Elberon Beauty-HD & 1.00 & & 15 & Le Grand Manitou-D & .50 & $\cdots$ \\
\hline $\begin{array}{l}13 \\
20\end{array}$ & El Dorado-D $\ldots \cdots$ & 2.00 & 1.0 & & Little Jewel-Min. D. & .75 & \\
\hline 20 & $\begin{array}{l}\text { E1 Granada-HD } \ldots \\
\text { Elite Glory-D } \ldots\end{array}$ & $\begin{array}{l}2 . \\
5 .\end{array}$ & $\begin{array}{l}1.25 \\
2.50\end{array}$ & $\begin{array}{r}3 \\
27\end{array}$ & Lois Delander-D . . & $\ddot{100}$ & $\cdots$ \\
\hline & $\begin{array}{l}\text { Elite Glor } \\
\text { Eliza Clar }\end{array}$ & & 00 & & $\begin{array}{l}\text { Lolita Velasco-HC } \\
\text { Lotus-D ......... }\end{array}$ & $\begin{array}{r}1.00 \\
.50\end{array}$ & $\ldots$ \\
\hline & $\begin{array}{l}\text { Eliza Clarke Bull-D } \\
\text { Ellinor Vanderveer-D }\end{array}$ & 2. & 1.2 & 5 & $\begin{array}{l}\text { Lotus-D } \\
\text { Lydia Poole- }-\mathrm{D}\end{array}$ & 2.00 & \\
\hline 31 & Elsie Daniels-HC .. & 2.00 & 1.00 & 27 & Mahogany $-\mathrm{C} \ldots$ & 2.00 & $\ddot{1.00}$ \\
\hline & Elsie Drexler-HC & 75 & & 5 & Marcella-D .. & .25 & \\
\hline 14 & Elsie Jane-D & 5.00 & 2.50 & 5 & Margaret $\mathrm{Ma}$ & 2.50 & 1.25 \\
\hline 6 & Embassador-D & 0 & & 19 & Wilson & 4. & 2.0 \\
\hline 32 & Emma Marie-HC & 2.00 & 1.00 & 10 & ssey-D $\ldots$ & 5.00 & 2.50 \\
\hline $\begin{array}{l}26 \\
26\end{array}$ & R. Holmes-C & .50 & $\cdots$ & 25 & uerite Bouchon-C .... & .50 & ... \\
\hline 20 & C & & & 5 & $M$ & & \\
\hline $\begin{array}{l}20 \\
16\end{array}$ & Eva Cole-HD .. & 5.00 & 2.50 & 22 & $\mathrm{n}-\mathrm{D}$ & 7.50 & 3.75 \\
\hline 16 & F. A. Kent-D & 2.00 & & 3 & tha Kemp-D & 10.00 & 5.00 \\
\hline & $1 \mathrm{di}-\mathrm{D}$ & 2.50 & 1.25 & 13 & a Washington-D .... & 1.00 & \\
\hline 22 & ing Meteor-D & & 2.50 & 17 & nistoph & & \\
\hline 34 & $=-\mathrm{S} \quad \cdots$ & .50 & $\cdots$ & 7 & M. F. Heaphy-D & 3.50 & 1.25 \\
\hline 14 & Florence Finger-D & .50 & & 10 & H. de Young-D & 2.00 & 1.00 \\
\hline 2 & Fordhook Gold Crest & 5.00 & 2.50 & 10 & Millionaire-D & .75 & $\cdots$ \\
\hline 2 & Fordhook Pearl-HC & 5.00 & 2. & 17 & Mina Burgle-D . & .35 & \\
\hline ? & ine $-D$ & 5 & & 2 & aflora-C & 5.00 & $2.5>>$ \\
\hline 19 & onmol & 0 & 7.50 & 2 & $\mathrm{Mi}$ & 1.50 & 1.0 \\
\hline $\begin{array}{l}19 \\
26\end{array}$ & Nashin & 7.50 & 3.75 & 5 & Miss California-D & 3.50 & 1.7 \\
\hline 26 & $H$ & 1.00 & & 27 & Miss New York-HC . & 2.50 & 1.2 \\
\hline
\end{tabular}




\section{INDEX-Continued}

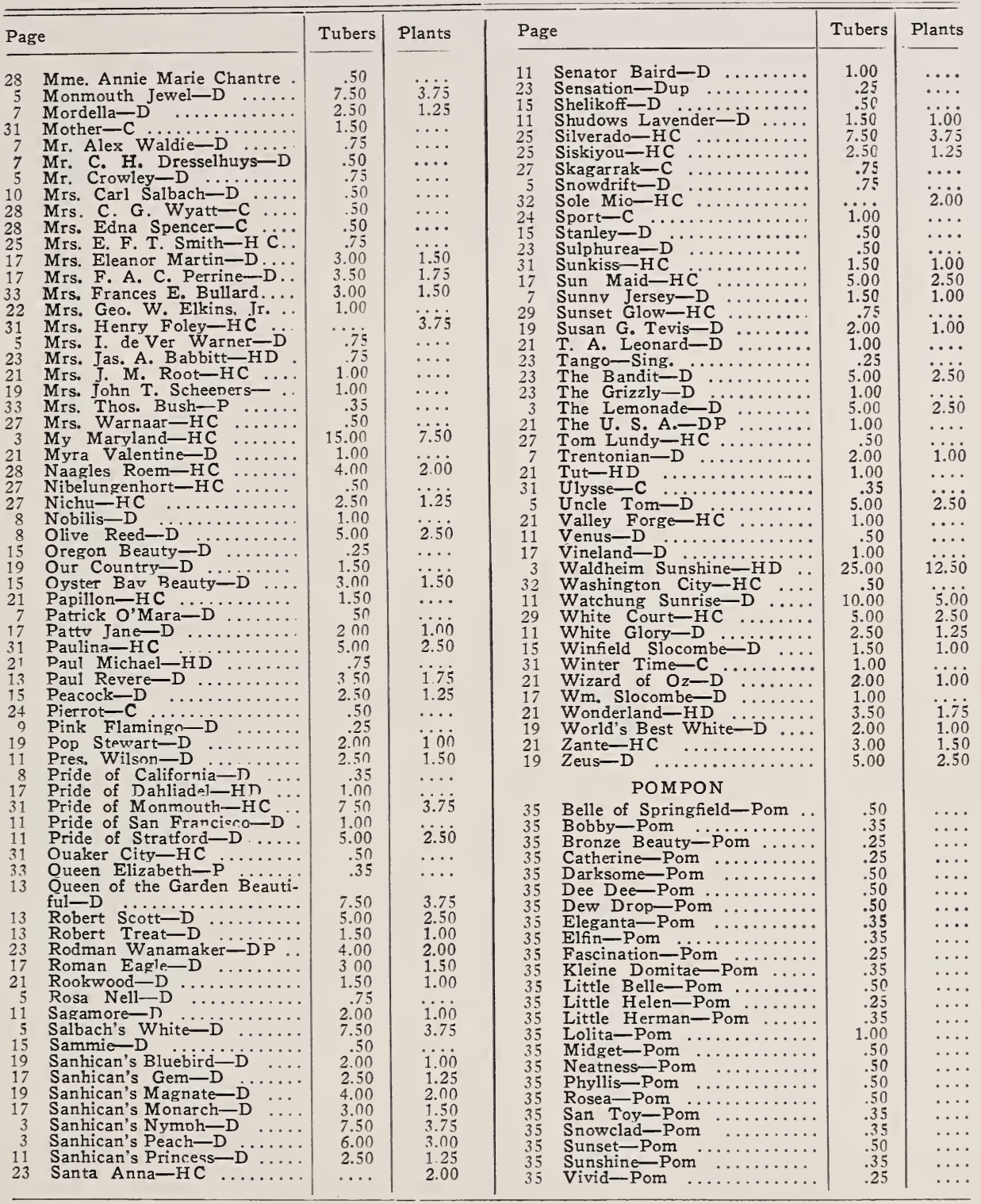

\section{DAHLIADEL NURSERIES}

WARREN W. MAYTROTT 


\section{FREE}

YOU MAY SELECT YOUR OWN COMPLIMENTARY TUBERS from the following list on orders for DAHLIA TUBERS from this catalog, except on collections and where noted. On each dollar you are allowed $25 \mathrm{c}$ toward any variety in this list. For example, on an order of $\$ 6.00$ worth of tubers you may select $\$ 1.50$ worth from the following list free, or a $\$ 2.00$ variety by paying $50 \mathrm{c}$ additional.

Amun Ra ......... \$.75

California Enchantress $\mathbf{. 5 0}$

Champagne ......... 1.50

Chas. Stratton ...... 2.00

Ellinor Vanderveer .. 2.50

Embassador ......... $\mathbf{. 5 0}$

Florence Finger ..... $\mathbf{. 5 0}$
Gladys Bates ......\$ .75

Harry Sheldon, Jr. .. $\mathbf{2 . 5 0}$

Insulinde ...........

Jersey's Gem ....... 1.00

La Grosse Bete ...... .75

Marcella ........... $\quad .25$

Mariposa ........... 1.00
Mrs. Edna Spencer ..\$ .50

Mrs. I. de Ver Warner $\mathbf{. 7 5}$

Mrs. Jas. A. Babbitt . .75

Paul Michael ........ .75

Robert Treat ....... 1.50

Skagarrak ........... $\quad .50$

Venus ..............50

POSITIVELY NO FREE TUBERS ON COLLECTIONS.

DAHLIAS of QUALITY and DISTINCTION mean for you, QUALITY tubers with all the health and vitality a well grown tuber should have, regardless of cost of production, and DISTINCTION by growing only the worthwhile varieties of the bright and pleasing shades and colors. Our 40 acres of healthy stock and 17,000 square feet of floor space completely equipped for growing, storing, and shipping dahlias, await your needs.

Your early order is invited to assure you of the widest selection of varieties.

12 of one variety for the price of 10 . 6 for the price of 5 .

Orders will be filled with strong field-grown root divisions unless green plants are specified. We will notify you if unable to supply any variety, as we do not substitute.

\section{OUR GUARANTEE}

All dahlia roots and plants, if properly cared for, are guaranteed true to name and free from disease, Mosaic or stunts to the extent of replacement with true stock. Tubers that fail to start in three weeks we will gladly replace upon their return. Satisfaction guaranteed. EARLY shipments for progagation are guaranteed true to name and to start growing in three weeks. We cannot go further than this as too much depends on the care given them.

\section{TERMS AND DELIVERY}

CASH WITH ORDER. Stamps accepted up to $\$ 2.00$, above that amount check, money order, or cash by registered mail. Tubers will be sent May 1st to May 15th by parcel post prepaid, unless shipment is C. O. D., in which case customer pays the C. O. D. charges. Shipments to sections where plantings are at a different time will be made accordingly.

WARNING. Do not send cash by mail unless you have it registered.

NOTICE ON GREEN PLANT SHIPMENTS. Plants will be shipped from May 14th to June 15th, but cannot be sent C. O. D. as this causes delay. When tubers and plants are ordered together, tubers will be held and shipped with the plants. If you are more than 200 to 300 miles from Vineland, we recommend plants should travel Parcel Post, "Special Handling." For this please add $\$ .25$ to your remittance. We pay all regular postage.

We guarantee plants as well as tubers to arrive in good condition, but cannot guarantee plants if shipped over 300 miles unless sent "Special Handling."

\section{DAHLIADEL NURSERIES}




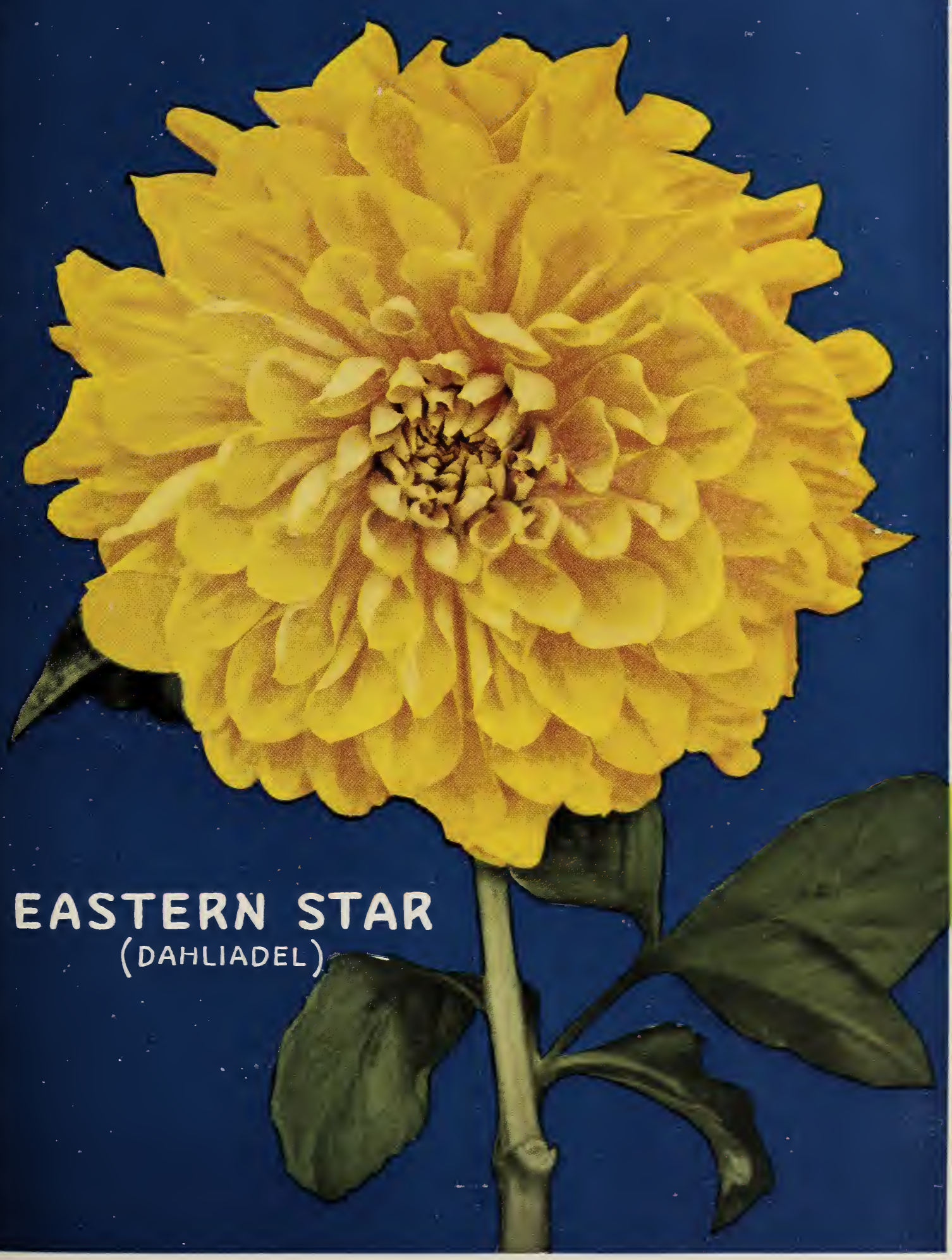




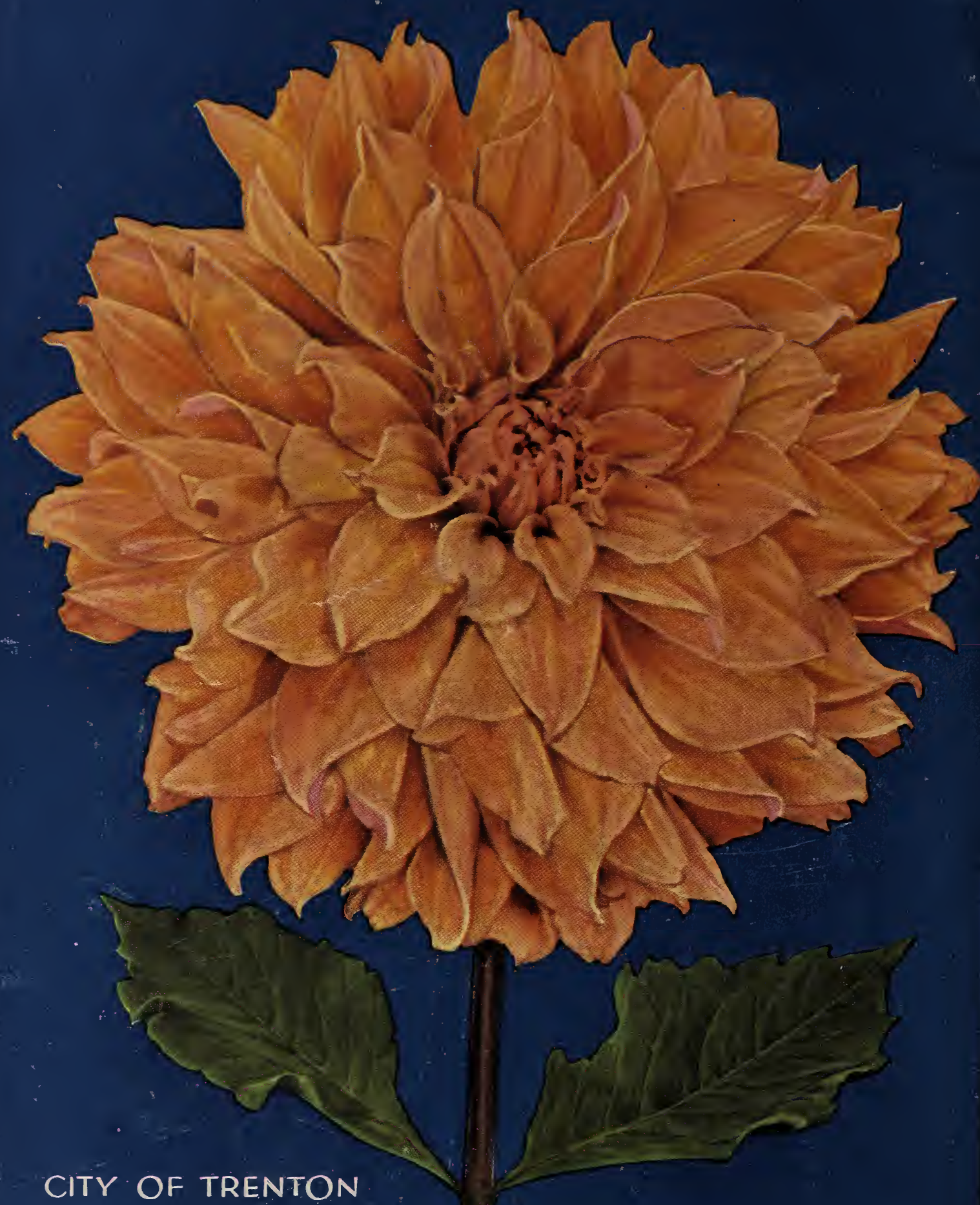

